\title{
Biological soil crusts on initial soils: organic carbon dynamics and chemistry under temperate climatic conditions
}

A. Dümig ${ }^{1}$, M. Veste ${ }^{2}$, F. Hagedorn ${ }^{3}$, T. Fischer ${ }^{4}$, P. Lange ${ }^{4}$, R. Spröte ${ }^{5}$, and I. Kögel-Knabner ${ }^{1,6}$

${ }^{1}$ Lehrstuhl für Bodenkunde, Department für Ökologie und Ökosystemmanagement, Wissenschaftszentrum Weihenstephan für Ernährung, Landnutzung und Umwelt, Technische Universität München, 85350 Freising-Weihenstephan, Germany

${ }^{2}$ Centrum für Energietechnologie Brandenburg e.V., Friedlieb-Runge-Strasse 3, 03046 Cottbus, Germany

${ }^{3}$ Department of Biogeochemistry, WSL, Swiss Federal Institute of Forest, Snow and Landscape Research, Zürcherstr. 111, 8903, Birmensdorf, Switzerland

${ }^{4}$ Brandenburg University of Technology at Cottbus, Faculty of Environmental Sciences and Process Engineering, Central Analytical Laboratory, Konrad-Wachsmann-Allee 6, 03046 Cottbus, Germany

${ }^{5}$ Chair of Soil Protection and Recultivation, Brandenburg University of Technology, Konrad-Wachsmann-Allee 6, 03046 Cottbus, Germany

${ }^{6}$ Institute for Advanced Study, Technische Universität München, Lichtenbergstrasse 2a, 85748 Garching, Germany

Biological soil crusts on initial soils
A. Dümig et al.
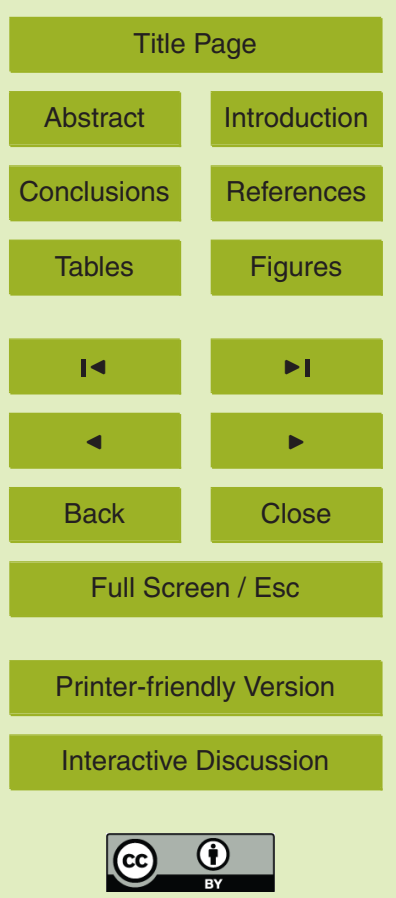
Received: 5 December 2012 - Accepted: 18 December 2012 - Published: 16 January 2013 Correspondence to: A. Dümig (duemig@wzw.tum.de)

Published by Copernicus Publications on behalf of the European Geosciences Union.

BGD

$10,851-894,2013$

Biological soil crusts on initial soils

A. Dümig et al.

Title Page

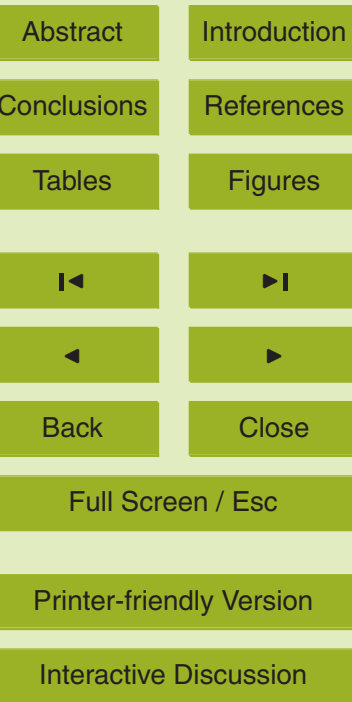

(c) (P) 


\section{Abstract}

Numerous studies have been carried out on the community structure and diversity of biological soil crusts (BSCs) as well as their important functions on ecosystem processes. However, the amount of BSC-derived organic carbon (OC) input into soils and

5 its chemical composition under natural conditions has rarely been investigated. In this study, different development stages of algae- and moss-dominated BSCs were investigated on a natural ( $<17 \mathrm{yr}$ old BSCs) and experimental sand dune ( $<4 \mathrm{yr}$ old BSCs) in northeastern Germany. We determined the OC accumulation in BSC-layers and the BSC-derived OC input into the underlying substrates for bulk materials and fractions $<63 \mu \mathrm{m}$. The chemical composition of OC was characterized by applying solid-state ${ }^{13} \mathrm{C}$ NMR spectroscopy and analysis of the carbohydrate-C signature. ${ }^{14} \mathrm{C}$ contents were used to assess the origin and dynamic of OC in BSCs and underlying substrates. Our results indicated a rapid BSC establishment and development from algae- to mossdominated BSCs within only $4 \mathrm{yr}$ under this temperate climate. The distribution of BSC

15 types was presumably controlled by the surface stability according to the position in the slope. We found no evidence that soil properties influenced the BSC distribution on both sand dunes. ${ }^{14} \mathrm{C}$ contents clearly indicated the existence of two OC pools in BSCs and substrates, recent BSC-derived OC and lignite-derived "old" OC (biologically refractory). The input of recent BSC-derived OC strongly decreased the mean residence time of total $\mathrm{OC}$. The downward translocation of $\mathrm{OC}$ into the underlying substrates was only found for moss-dominated BSCs at the natural sand dune which may accelerate soil formation at these spots. BSC-derived OC mainly comprised O-alkyl C (carbohydrate- $\mathrm{C}$ ) and to a lesser extent also alkyl $\mathrm{C}$ and $\mathrm{N}$-alkyl $\mathrm{C}$ in varying compositions. Accumulation of alkyl $\mathrm{C}$ was only detected in BSCs at the experimental dune which may induce a lower water solubility of BSC-derived extracellular polymeric substances when compared to BSCs at the natural sand dune indicating that hydrological effects of BSCs on soils depend on the chemical composition of the extracellular polymeric substances.
BGD

$10,851-894,2013$

Biological soil crusts on initial soils

A. Dümig et al.

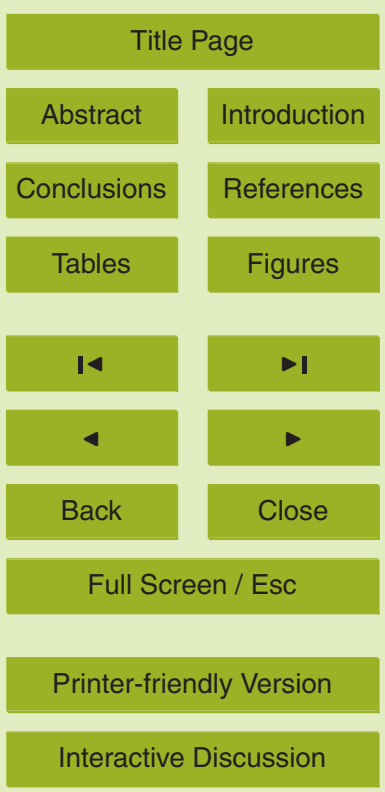

Interactive Discussion 


\section{Introduction}

Biological soil crusts (BSCs) are an association of soil particles and microorganisms (cyanobacteria, algae, bryophytes, fungi, lichens) in varying composition which cover the uppermost and vegetation-free soil surface in many ecosystems (Belnap and 5 Lange, 2001). As first colonizers BSCs are important producers in many initial ecosystems as well mature ecosystems with a sparse vegetation cover from the deserts to polar regions (Langhans et al., 2009; Schaaf et al., 2011). It is assumed that cyanobacterial and green algae BSCs are the earliest successional stage of BSCs which are replaced by lichen- and moss-dominated BSCs during later stages of BSC developpreviously bare substrate is controversialy discussed and is influenced by the spatial scale of disturbance, the substrate and the climatic boundary conditions. From deserts the reported recovery time after disturbance ranges from decades to centuries (Belnap and Eldridge, 2003; Maestre et al., 2011), while small-scale disturbance can be closed by cyanobacteria and green algae in 1-2 yr (Veste et al., 2001a; Dojani et al., 2011). Under temperate climate, Fischer et al. (2010a) observed the development of BSC already after three years on an artificial watershed.

Several studies revealed the important effect of BSCs on water availability and hydrological processes (e.g. Maestre et al., 2002; Belnap, 2006; Fischer et al., 2010b; Yair et al., 2011), plant establishment (e.g. Prasse and Bornkamm, 2000; Beyschlag et al., 2008), soil stability (e.g. Belnap and Gardner, 1993; Mazor et al., 1996; Lázaro et al., 2008), C and N fixation (Beymer and Klopatek, 1991; Belnap, 2002; Brankatschk et al., 2012) as well as soil fertility (e.g. Lange et al., 1992; Reynolds et al., 2001), and thus the significant influences of BSCs on ecosystem functioning, development and 25 health (Veste et al., 2011; Castillo-Monroy et al., 2011; Maestre et al., 2011). As photoautotroph organisms these microorganisms play a key-role for the net carbon fluxes in microphytes-dominated ecosystems (Beymer and Klopatek, 1991; Wilske et al., 2008; Elbert et al., 2012).
BGD

$10,851-894,2013$

Biological soil crusts on initial soils

A. Dümig et al.

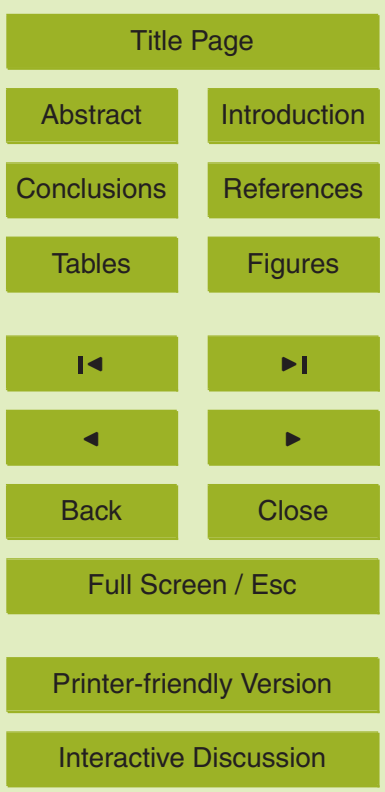

Interactive Discussion 
So far, the amount of BSC-derived OC input into soils and its chemical composition was rarely investigated, especially under in situ conditions. Similarly, the effect of BSC colonization of the uppermost millimeters of the soil surface on soils beneath the BSC is still unclear. Bacteria and algae produce extracellular polymeric substances 5 (EPS) comprising a large range of different biopolymers which mediate the adhesion of EPS to mineral surfaces (Flemming and Wingender, 2010). OC accumulation increases mineral weathering (Amit and Harrison, 1995; Drever and Stillings, 1997; Chen et al., 2009). Therefore, it can be expected that the effects of EPS on initial soil formation are more intense if EPS compounds are water soluble and thus, moveable into greater 10 soil depth. There is only one study (Beymer and Klopatek, 1991) which demonstrated a downward translocation of $\mathrm{OC}$ from the BSC into the underlying soil by using a ${ }^{14} \mathrm{CO}_{2}$ chamber experiment. This labile and leachable $\mathrm{OC}$ is considered to be an important source of nutrition to the large mass of heterotrophic soil microorganisms (Beymer and Klopatek, 1991).

15 In this study, we investigated different development stages of BSCs (algae- and moss-dominated) on a natural $(<17 \mathrm{yr}$ old) and experimental sand dune ( $<4 \mathrm{yr}$ old) in northeast Germany. Our objectives were to (I) determine the amount of OC fixation in BSC-layers and the BSC-derived OC input into the underlying substrates; (II) characterize the chemical composition of OC in BSCs and substrates (bulk materials and fractions $<63 \mu \mathrm{m}$ ) by applying solid-state ${ }^{13} \mathrm{C}$ NMR spectroscopy and analyses of the carboydrate signature (hydrolysis with trifluoroacetic acid); and (III) to assess the OC dynamic and timescales of BSC establishment by using radiocarbon analysis in combination with the known ages of the sand dunes.

\section{BGD}

10, 851-894, 2013

\section{Biological soil crusts on initial soils}
A. Dümig et al.

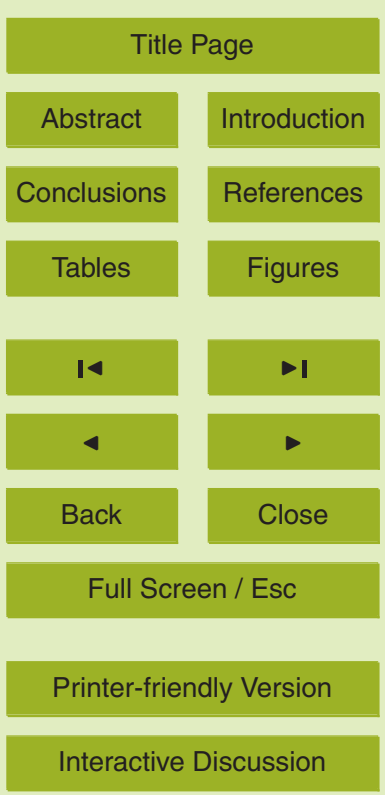




\section{Material and methods}

\subsection{Study sites, sampling and description of biological soil crusts}

We investigated one natural (ND) and one experimental (ED) sand dune in Brandenburg (northeast Germany) under a temperate climate with a sub-continental character 5 (mean annual rainfall: $560 \mathrm{~mm}$, mean annual temperature: $9^{\circ} \mathrm{C}$ ). At each sand dune five different development stages of BSCs were defined along a catena which generally differ in the location on the slope, vegetation cover (mainly the grass species Corynephorus canescens) and composition of BSC organisms (Fig. 1). The early successional stages of the BSCs include cyanobacteria and above all green algae (mainly 10 Zygogonium ericetorum Kützing). The moss cover consisted of Polytrichum piliferum Hedw. A detail list of species occurring on European sand dunes is given by Fischer et al. (2012). For simplification, BSC-types will be denominated as algae- and mossdominated BSCs in the following. The natural sand dune with maximum age of $17 \mathrm{yr}$ represents a mobile dune (Pleistocene sand) which is located in an area where former military activities (until about 1992) caused extensive disturbances of the land surface. Here, the BSC-sequence starts with a mobile phase (bare substrate) on top of the dune where disturbances by wind impedes the development of BSC. We found different BSC-types with increasing distance from the top of the dune along the lee slope and further to the characteristic dry acidic grassland dominated by Corynepho20 rus canescens (Jentsch and Beyschlag, 2003). The experimental sand dune is located in a distance of about $60 \mathrm{~km}$ from the natural sand dune in the recultivated landscape of the Lusatian open-cast lignite mining district near Cottbus. It was constructed in 2001 by dumping Quaternary sandy substrate, and is about $50 \mathrm{~m}$ long, $1.5 \mathrm{~m}$ high, and $7 \mathrm{~m}$ wide. At the experimental sand dune no BSC-layers were found until the year 2006.

25 When compared to the natural sand dune, the major difference is that a mobile phase is missing and the catena starts with incipient BSCs. Generally, the thicknesses of BSCs increased from the mobile sand (at ND) or incipient BSC (at ED) to algae-dominated BSC and further to moss-dominated BSC.
BGD

$10,851-894,2013$

Biological soil crusts on initial soils

A. Dümig et al.

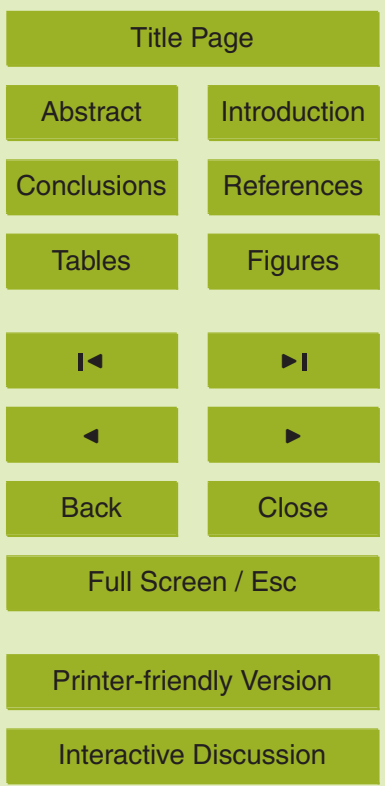


At both sand dunes, the five spots with BSCs (at the ND one spot with mobile sand and four spots with BSCs) were sampled in two depth intervals in 2009: BSCs (0maximal $15 \mathrm{~mm}$ depth) and the substrate below the BSC up to $3 \mathrm{~cm}$ depth. BSCs and substrates at all spots were sampled in triplicate with exception of the substrate at the

\subsection{Fractionation}

Density fractionation with a Na polytungstate solution $\left(1.7 \mathrm{~g} \mathrm{~cm}^{-3}\right)$ was used to seperate the light fractions from the mineral soil components with a density $>1.7 \mathrm{~g} \mathrm{~cm}^{-3}$ in the BSCs. This was done for pooled samples out of aliquots from all three repli10 cates of a BSC type. The light fractions were washed with deionized water on a $20 \mu \mathrm{m}$ mesh sieve. Afterwards, BSCs and substrate bulk materials $(<2 \mathrm{~mm})$ were fractionated according to particle-size without sonification as the soil materials showed no aggregation. In consideration of the dominance of coarse particles, we only separated the sand fraction $(63-2000 \mu \mathrm{m})$ from the finer particles $(<63 \mu \mathrm{m}$, silt and clay) by wet sieving. 15 The fine particles were evaporated with a rotary film evaporator and recovered from the suspensions by freeze drying.

\subsection{General characterization of BSCs and substrates}

Undisturbed samples (0-3 cm depth) were collected for each replicate for bulk density measurement. Total carbon and nitrogen contents were determined by combustion (EIementar Vario EL). As all samples were carbonate-free, the measured $\mathrm{C}$ is completely organic. Bulk materials were treated with $\mathrm{NH}_{4}$-oxalate $\left(\mathrm{Al}_{0}, \mathrm{Fe}_{0}, \mathrm{Si}_{0}\right)$ and dithionitecitrate-biocarbonate (DCB: $\mathrm{Al}_{d}, \mathrm{Fe}_{\mathrm{d}}, \mathrm{Si}_{\mathrm{d}}$ ) using the method of Schwertmann (1964) and Mehra and Jackson (1960), respectively. The Al, Fe and Si concentrations were measured with an ICP-OES (Varian Vario-Pro). For the artifical sand dune results from texture analyzes (pipette method) were determined by a former study at the same sampling plots (Spröte et al., 2010).
BGD

$10,851-894,2013$

Biological soil crusts on initial soils

A. Dümig et al.

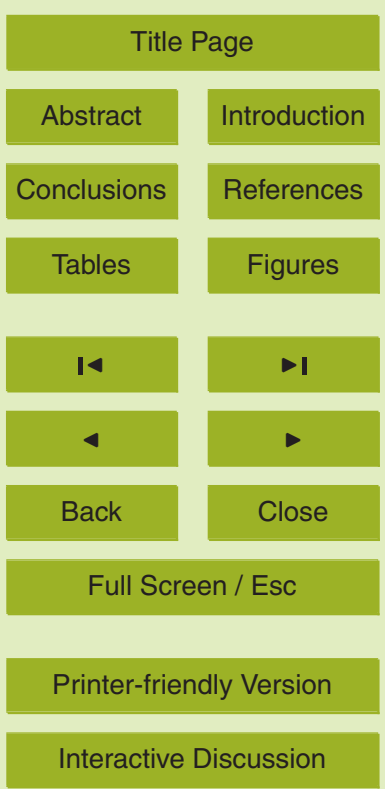




\subsection{Solid-state ${ }^{13} \mathrm{C}$ NMR spectroscopy}

Mineral fractions $<63 \mu \mathrm{m}$ from BSCs and substrates, light fractions and bulk materials from BSCs with sufficiently high OC concentration were analyzed by solid-state ${ }^{13} \mathrm{C}$ NMR spectroscopy (Bruker DSX 200 NMR spectrometer) using the cross-polarization 5 magic angle spinning (CPMAS) technique (Schaefer and Stejskal, 1976) with a spinning speed of $6.8 \mathrm{kHz}$ and a contact time of $1 \mathrm{~ms}$. A ramped ${ }^{1} \mathrm{H}$-pulse starting at $100 \%$ power and decreasing until $50 \%$ was used during contact time to avoid HartmannHahn mismatches (Peersen et al., 1993). The pulse delays were 400 ms (bulk materials and mineral fractions $<63 \mu \mathrm{m}$ ) and $2000 \mathrm{~ms}$ (light fractions). In dependence of

10 the signal-to-noise ratio, a line broadening between 50 and $100 \mathrm{~Hz}$ was used prior to Fourier transformation. The chemical shifts of ${ }^{13} \mathrm{C}$ were referred to external tetramethylsilane $(=0 \mathrm{ppm})$. For quantification, the spectrum was divided into four major chemical shift regions according to Knicker and Lüdemann (1995) (0 to 45 ppm: alkyl-C, 45-60 ppm: N-alkyl C, 60 to 110 ppm: O-alkyl-C, 110 to 160 ppm: aromatic C, 160 15 to 220 ppm: carboxyl-C) over which was integrated. The occurrence of spinning side bands due to insufficient averaging of the chemical shift anisotropy at the used spinning speed was considered by adding their intensities to that of the parent signal (Knicker and Lüdemann, 1995).

\subsection{Determination of neutral sugars}

20 Sugar monomers were analyzed for BSCs (bulk material and fraction $<63 \mu \mathrm{m}$ ), substrate (fraction $<63 \mu \mathrm{m}$ ) and light fractions according to Eder et al. (2010), which is modified from the methods of Amelung et al. (1996) as well as Rumpel and Dignac (2006). Briefly, the samples were hydrolyzed with $4 \mathrm{M}$ trifluoroacetic acid (TFA) at $105^{\circ} \mathrm{C}$ for $4 \mathrm{~h}$. After the samples had cooled down, an internal standard (methylglucose) was added for calculating the recovery. Thereafter, the hydrolyzed samples were purified by filtration over glass fibre membrane and dried using a rotary evaporator $\left(40^{\circ} \mathrm{C}\right)$. Instead of ammonia, ethylenediaminetetraacetic acid (EDTA) was added to

BGD

$10,851-894,2013$

Biological soil crusts on initial soils

A. Dümig et al.

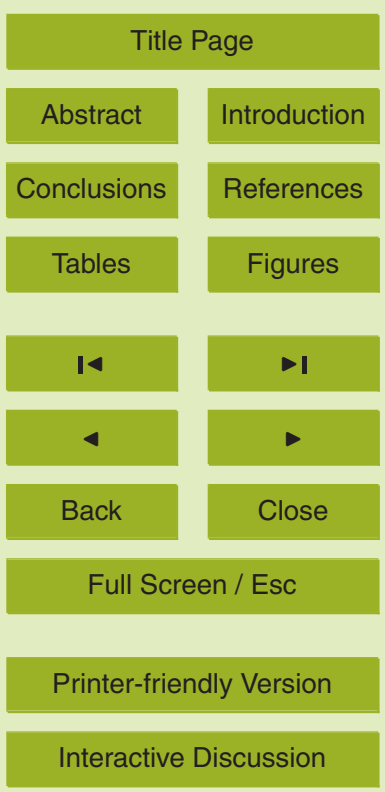


keep iron ions in stable, soluble complexes and to avoid possible co-precipitation of dissolved organic carbon. Derivatisation of the sample was carried out in screw top test tubes. Aldoses were reduced to their corresponding alditols after addition of $\mathrm{NaBH}_{4}$ dissolved in dimethyl sulfoxide (DMSO). Simultaneously, myoinositol was added for 5 calculating the GC response factor. Acetylation was carried out by adding acetic anhydride and glacial acetic acid, and methylimidazole was used as catalyst. After $10 \mathrm{~min}$, the reaction was stopped by adding ice cold deionised water. The derivatized sugar monomers were extracted by liquid-liquid extraction with dichloromethane. GC analysis was performed on a GC Agilent 6890 (Agilent Technologies, Germany) equipped with 10 a FID. The sugar monomers were separated with a $60 \mathrm{~m}$ fused silica capillary column (BPX 70, SGE GmbH, Germany). The temperature program started at $180^{\circ} \mathrm{C}$ (isothermal for $3 \mathrm{~min}$ ) and increased to $230^{\circ} \mathrm{C}$ at $5^{\circ} \mathrm{C} \mathrm{min}-1,23 \mathrm{~min}$ isothermal at $230^{\circ} \mathrm{C}$. The concentration of individual sugar monomers (arabinose, fucose, galactose, glucose, mannose, rhamnose, ribose, xylose) was calculated based upon the internal standard 15 myoinositol. The recovery of the standard methylglucose varied between 67 and $96 \%$.

\section{$2.6{ }^{14} \mathrm{C}$ analyses}

For measurements of the ${ }^{14} \mathrm{C}$ contents, selected BSCs and substrates (fractions $<63 \mu \mathrm{m}$ ) were graphitized and analyzed at the accelerator mass spectrometry (AMS) facility of the ETH-PSI, Zürich. The radiocarbon contents are reported as percent mod20 ern carbon (pMC), i.e. relative to the ${ }^{14} \mathrm{C}$ content of the internationals standard (1950 AD) after background correction and $\delta^{13} \mathrm{C}$ normalization (Trumbore, 2009). Conventional radiocarbon ages were calculated following the convention of Stuiver and Pollach (1977) and calibrated using the OxCal program (Bronk Ramsey, 2001). The precision of ${ }^{14} \mathrm{C}$ measurements was \pm 0.32 percent modern carbon (30-35 yr BP).

25 The amount of lignite $(\mathrm{L})$ in fractions $<63 \mu \mathrm{m}$ as percentage of total organic carbon was calculated by using a mass balance equation according to Klouda et al. (1996)

\section{BGD}

10, 851-894, 2013

Biological soil crusts on initial soils
A. Dümig et al.

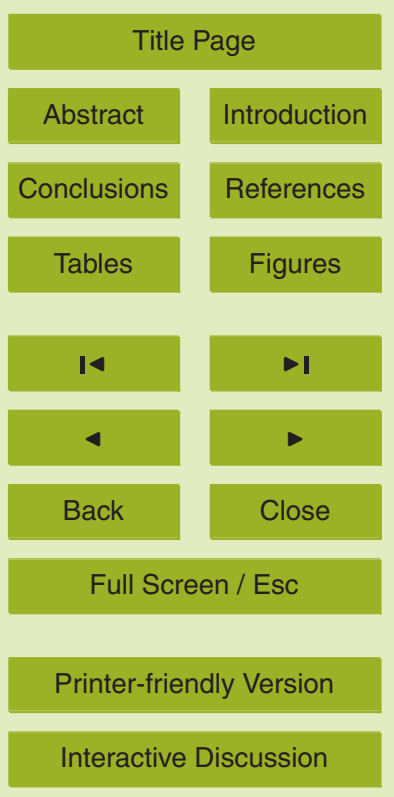


and Rumpel et al. (2003):

$L(\%)=\left[1-\left({ }^{14}\right.\right.$ Cactivity $_{\text {measured }} /{ }^{14}$ Cactivity of recent BSC material $\left.)\right] \times 100$

BGD

$10,851-894,2013$

As living organisms like BSCs and plants maintain a ${ }^{14} \mathrm{C} /{ }^{12} \mathrm{C}$ ratio which is identical 5 to those of the atmospheric $\mathrm{CO}_{2}$ (Trumbore, 2009), the ${ }^{14} \mathrm{C}$ content of recent BSC material equates with the ${ }^{14} \mathrm{C}$ activity of atmospheric $\mathrm{CO}_{2}$. With reference to the year of sampling in 2009, BSCs at the natural sand dune had a maximum age of $17 \mathrm{yr}$ and at the experimental sand dune BSCs had been existing for $4 \mathrm{yr}$. Therefore, we calculated the mean lignite content by using average ${ }^{14} \mathrm{CO}_{2}$ activities for the above mentioned 10 periods (1992-2009 and 2006-2009). Atmospheric ${ }^{14} \mathrm{CO}_{2}$ values were obtained from Levin and Kromer (2004) for the period 1992-2003 (pMC values range between 113.1 and 106.6) and from I. Levin (2012, personal communication) for the period 2004-2009 (pMC values range between 106.0 and 104.2).

\section{Results}

\subsection{General characteristics of BSCs and substrates}

The natural (ND, <17yr old) and experimental (ED, <4yr old) sand dune had parent substrates below BSCs with similar physical properties (Table 1). Bulk densities $(0-3 \mathrm{~cm})$ varied between $1.4-1.6 \mathrm{~g} \mathrm{~cm}^{-3}$ and $1.5-1.7 \mathrm{~g} \mathrm{~cm}^{-3}$ at the natural and experimental sand dune, respectively. As expected, both sand dunes showed low portions of the particle-size fraction $<63 \mu \mathrm{m}$ with a maximum of 2.7 mass-\% (Table 1 ). In most BSCs, the portion of the fraction $<63 \mu \mathrm{m}$ was higher when compared to the corresponding substrates. The experimental sand dune showed slightly higher portions of the fraction $<63 \mu \mathrm{m}$ than the natural sand dune. The texture analyses of samples from the experimental sand dune revealed slightly higher silt and clay contents of BSCs when compared to the substrates which is in line with portions of the fraction $<63 \mu \mathrm{m}$.

Biological soil crusts on initial soils

A. Dümig et al.

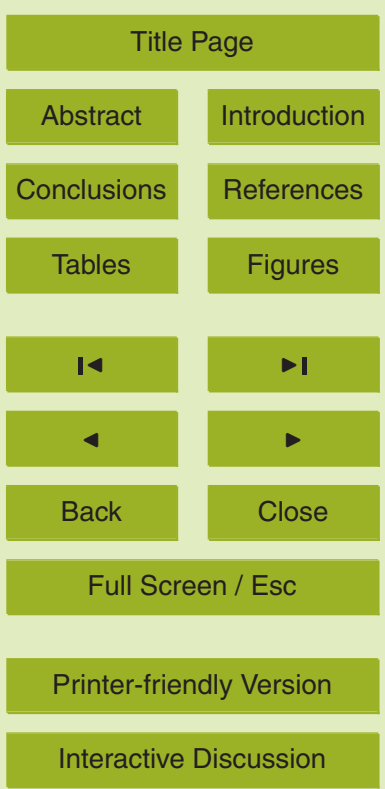

Interactive Discussion 
At both sand dunes, we found no difference of oxalate and DCB-extractable $\mathrm{Al}, \mathrm{Fe}$ and Si between the different development stages of BSCs. The experimental sand dune showed slightly higher $\mathrm{Fe}_{\mathrm{o}}$ and $\mathrm{Fe}_{\mathrm{d}}$ concentrations of BSCs and substrates when compared to those of the natural sand dune. pH values $\left(\mathrm{H}_{2} \mathrm{O}\right)$ of $\mathrm{BSC}$ were also similar 5 between the natural $(5.0 \pm 0.1)$ and experimental $(5.1 \pm 0.2)$ sand dune, and no marked changes were detected between the different types of BSCs.

\section{$3.2{ }^{14} \mathrm{C}$ contents}

Due to the very low OC contents of bulk materials, ${ }^{14} \mathrm{C}$ contents were determined for fractions $<63 \mu \mathrm{m}$ which are presented in Table 2. The experimental sand dune showed markedly lower pMC (percent modern carbon, $100 \mathrm{pMC}=1950$ ) values or higher radiocarbon ages for substrates (50-60 pMC) and BSCs (64-82 pMC) when compared to those from the natural sand dune (substrates: 92-99 pMC, BSCs: 93-100 pMC). For both sand dunes, pMC values were higher in BSCs than in the corresponding substrates with exception of the mobile sand at the natural sand dune.

For BSCs at the natural sand dune (ND), we found continuously increasing pMC values from the mobile sand to algae-dominated BSCs $(N D 2,3)$ and further to mossdominated BSCs (ND4,5). In the latter, we observed the incorporation of bomb-spike ${ }^{14} \mathrm{C}$ and thus, of rapidly cycling constituents with pMC values of above 100 (Trumbore et al., 1995). The corresponding substrates underlying the mobile sand (ND1) 20 and algae-dominated BSCs (ND2,3) showed comparable pMC values (ca. 93 pMC, 525-585 yr BP) which were also similar to those from the uppermost millimeters of the mobile sand. In contrast, pMC values of substrates below moss-dominated BSCs (ND4,5) were clearly higher (97-99 pMC, 55-205 yr BP).

On the crest of the experimental sand dune (ED), pMC values of BSCs decreased 25 from algae-dominated BSCs to moss-dominated BSCs. A trend of increasing pMC values were detected among moss-dominated BSCs along the slope: crest < backslope $<$ footslope. The substrates of the experimental sand dune showed two different levels
BGD

$10,851-894,2013$

Biological soil crusts on initial soils
A. Dümig et al.

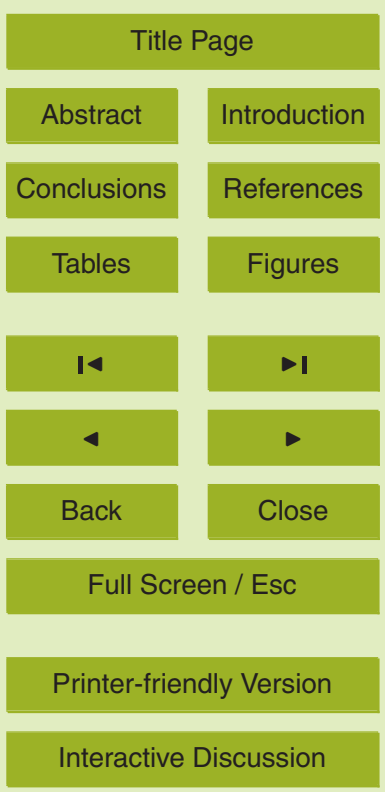


of pMC values (ED1, 3: 60 pMC; ED2, 4, 5: 50-52 pMC) which were independent from the overlying BSC type.

Finally, the low ${ }^{14} \mathrm{C}$ contents (or old ${ }^{14} \mathrm{C}$ ages) of BSCs and substrates from both sand dunes point to the contribution of old and refractory $\mathrm{OC}$ to the total organic carbon pool.

\section{3.3 Total organic carbon and nitrogen content}

As shown in Table 1, two different levels of total OC content were found for the substrates of the natural sand dune (ND). The substrates below the mobile sand (ND1) and algae-dominated BSC (ND2, 3) had lower values $\left(0.8 \mathrm{mgg}^{-1}\right)$ when compared to those below BSC with mosses (ND4, 5; $2.0 \mathrm{mgg}^{-1}$ ). In BSCs, total OC contents were 10 larger than in the substrate and continuously increased from ND1 $\left(0.7 \mathrm{mgg}^{-1}\right.$; mobile sand) to ND5 $\left(9.6 \mathrm{mgg}^{-1}\right)$. Compared to the bulk material, the corresponding fractions $<63 \mu \mathrm{m}$ showed considerably higher total OC contents for BSCs $\left(69-147 \mathrm{mgg}^{-1}\right)$ and substrates (43-120 $\mathrm{mgg}^{-1}$ ) (Table 1).

At the experimental sand dune (ED), the substrates (bulk materials) similarly showed 15 low total OC contents $\left(1.1 \pm 0.2 \mathrm{mg} \mathrm{g}^{-1}\right)$ below the different development stages of BSCs (Table 1). The total OC contents of BSCs were larger than in the substrate for bulk materials and fractions $<63 \mu \mathrm{m}$ (Table 1). They increased from algae-dominated BSC to BSC with mosses on the crest (ED3; $8.5 \mathrm{mg} \mathrm{g}^{-1}$ ), whereas lower values were detected for BSCs with mosses on the slope (ED4, 5). Fractions < $63 \mu \mathrm{m}$ (BSCs and substrates) 20 showed lower total OC contents when compared to those from the natural sand dune.

The above presented OC contents comprised not only recent OC from BSCs, but also old and refractory OC (see Sect. 3.2). Therefore, we calculated the amount of this refractory pool of OC (see Sect. 2.6) by using ${ }^{14} \mathrm{C}$ contents, and hence the BSCderived $\mathrm{OC}$ input. In the following only lignite-corrected values will be presented and

discussed. In consideration of the small distance between the sampling spots of the three replicates (ca. $1 \mathrm{~m}^{2}$ ) it can be expected that the three replicates had similar lignite contents. Under this assumption we also calculated the BSC-derived OC inputs as mean value of three replicates (Table 3 ). In addition, we transferred the lignite-C
BGD

$10,851-894,2013$

Biological soil crusts on initial soils

A. Dümig et al.

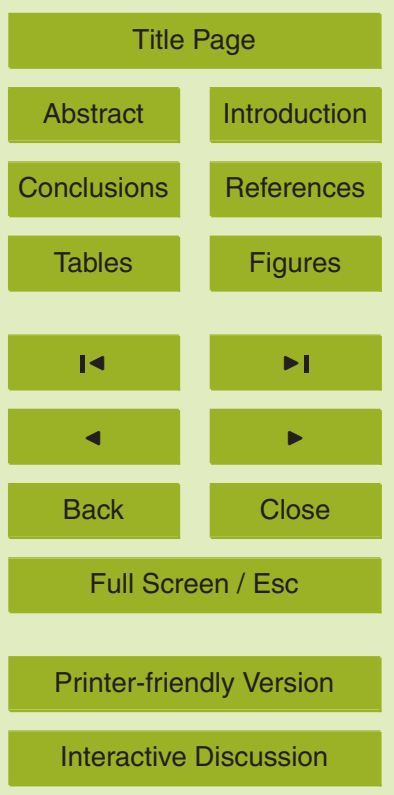

Interactive Discussion 
contents to bulk materials as information from other studies about BSC-derived OC accumulation is rare and only related to bulk materials (Table 3 ).

For bulk materials, the range of $\mathrm{BSC}$-derived $\mathrm{OC}$ input $\left(\mathrm{OC}_{\mathrm{BSC}}-\mathrm{OC}_{\text {substrate }}\right)$ was similar between the natural $\left(0.8-7.2 \mathrm{mgg}^{-1}\right)$ and experimental $\left(1.7-4.6 \mathrm{mg} \mathrm{g}^{-1}\right)$ sand dune

5 (Table 3), but differed strongly in dependence of the BSC development stage (Fig. 2) as algae-dominated BSC showed lower inputs of OC than BSCs with mosses. When compared to bulk materials, fractions $<63 \mu \mathrm{m}$ showed much larger OC inputs from BSCs (Table 3). We also calculated the BSC-derived OC inputs inclusive of the refractory OC pool. These were only slightly lower indicating similar amounts of old and refractory $O C$ in BSCs and substrates (Table 3). Nitrogen contents were low at both sand dunes, and near or below the detection limit in substrates. Generally, larger N contents were found for BSCs when compared to substrates as well as at the experimental when compared to natural sand dune.

\subsection{Overall chemical composition as revealed by solid-state ${ }^{13} \mathrm{C}$ NMR spectroscopy}

Besides fractions $<63 \mu \mathrm{m}$ from BSCs und substrates (Table 2), ${ }^{13} \mathrm{C}$ NMR spectra were obtained from selected BSC bulk materials (three samples from ND4, 5; four samples from ED2, 5) with sufficiently high OC content. The mean relative proportions of functional groups revealed that BSC bulk materials from the experimental sand dune (18 $\pm 1 \%$ alkyl-C, $37 \pm 4 \%$ O-alkyl-C, $23 \pm 3 \%$ aromatic C, $17 \pm 3 \%$ carboxyl-C, $7 \pm 1 \%$ $\mathrm{N}$-alkyl C) showed higher proportions of aromatic $\mathrm{C}$, carboxyl $\mathrm{C}$ and alkyl $\mathrm{C}$, but lower O-alkyl C proportions when compared to those from the natural sand dune $(16 \pm 2 \%$ alkyl-C, $53 \pm 4 \%$ O-alkyl-C, $13 \pm 3 \%$ aromatic C, $11 \pm 4 \%$ carboxyl-C, $7 \pm 1 \% \mathrm{~N}$-alkyl C). Similar differences in the chemical composition of BSCs between both sand dunes 25 were also identified for fine fractions from BSCs and substrates. Generally, BSC bulk materials from both sand dunes showed higher proportions of O-alkyl C (2-13\%) and aromatic C (1-7\%), and lower ones of alkyl C (4-16\%) in comparison with the corresponding BSC fine fractions. The major difference between the BSC types was the

BGD

$10,851-894,2013$

Biological soil crusts on initial soils
A. Dümig et al.

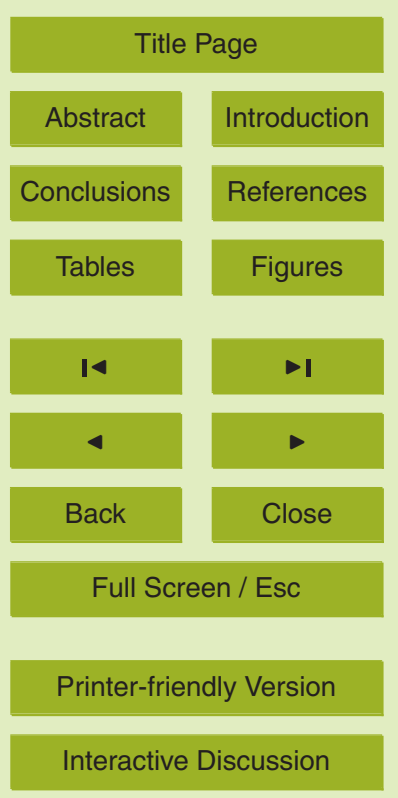


proportion of O-alkyl $\mathrm{C}$ which was highest at BSCs with mosses (AD4, 5 and ND4, 5). We calculated the qualitative changes in the chemical composition of the upper millimeters of the soil surface due to the colonization of BSCs $\left({ }^{13} \mathrm{C}\right.$ NMR spectra $\mathrm{BSC}^{-}{ }^{13} \mathrm{C}$

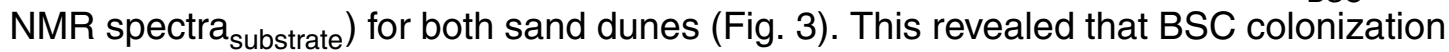
5 mainly results in the accumulation of $\mathrm{O}$-alkyl $\mathrm{C}$, alkyl $\mathrm{C}$ and $\mathrm{N}$-alkyl $\mathrm{C}$. Further, BSCs at the natural sand dune accumulate more O-alkyl $\mathrm{C}$, but not alkyl $\mathrm{C}$ as compared to those of the experimental sand dune.

\subsection{Carbohydrate signature of OC}

The carbohydrate-C contents of BSCs (bulk materials and fractions $<63 \mu \mathrm{m}$ ) and 10 substrates (fractions $<63 \mu \mathrm{m}$ ) for both sand dunes are shown in Fig. 4 and Table 4. A wide range of carbohydrate- $C$ contents for the different development stages of BSCs (bulk material) were found at the natural $\left(46-721 \mathrm{mgg}^{-1} \mathrm{OC}\right.$ ) as well as experimental (323-597 $\mathrm{mg} \mathrm{g}^{-1} \mathrm{OC}$ ) sand dune comprising monosaccharides from plantderived hemicelluloses and microbial products, as trifluoroacetic acid does not release crystalline cellulose. The change from initial substrate conditions to algae-dominated BSCs, and to BSCs with the contribution of mosses was combined with strongly increasing carbohydrate- $C$ contents at the natural dune (Fig. 4). At the experimental sand dune, the increase of carbohydrate- $C$ was lower from algae-dominated BSCs to BSCs with mosses. Figure 5 illustrates the difference in the accumulation of $O C$ and 20 carbohydrate-C in BSCs between both sand dunes. BSCs at the natural sand dune accumulated more carbohydrate-C per gram OC than BSCs at the experimental sand dune. Almost all BSCs had high ratios of galactose plus mannose over arabinose plus xylose $(\mathrm{GM} / \mathrm{AX})$ of $>2$. The highest $\mathrm{GM} / \mathrm{AX}$ ratios (or lacking contributions of arabinose and xylose at the natural dune) were found for initial substrate conditions and

algae-dominated BSCs (Table 4) without other vegetation in the vicinity of BSCs. At the experimental sand dune, bulk materials of BSCs showed higher carbohydrate-C contents per gram OC as well as higher GM/AX ratios than fractions $<63 \mu \mathrm{m}$ from BSCs and substrates (Fig. 4, Table 4). This is similar at the natural sand dune apart from the

BGD

$10,851-894,2013$

Biological soil crusts on initial soils

A. Dümig et al.

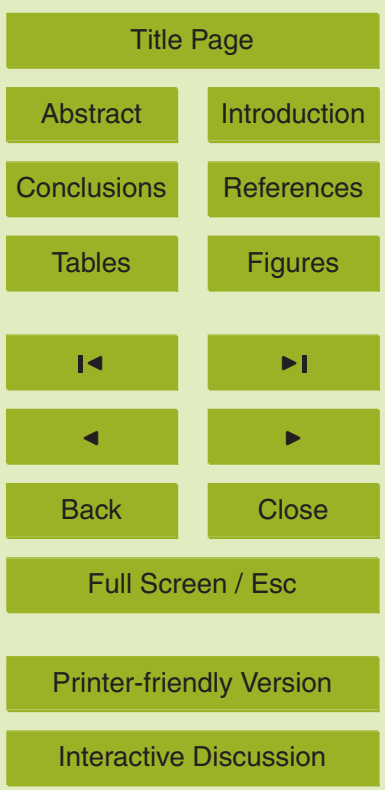


mobile sand (ND1) and algae-dominated BSCs (ND2, 3) where fractions < $63 \mu \mathrm{m}$ from BSCs showed the highest carbohydrate-C contents. With exception of the mobile sand at the natural sand dune, the subjacent substrate (fraction $<63 \mu \mathrm{m}$ ) showed the lowest carbohydrate- $C$ contents at both sand dunes.

\section{Discussion}

\subsection{OC sources in BSC-layers and substrates: evidence from radiocarbon analysis}

The high ${ }^{14} \mathrm{C}$ ages measured in BSC of up to $3500 \mathrm{yr}$ clearly indicate that BSC comprised not only of rapidly cycling, recently assimilated carbon by microbial communisand dunes are located within an open-cast lignite mining area, the contribution of lignite-derived ash or dust to the total SOC pool can be expected due to atmospheric depositions (Rumpel et al., 1998). In addition, the Quaternary sandy substrate which was used to dump the experimental sand dune may have been contaminated with 15 lignite-derived carbonaceous particles. Indications for this assumption arise from lignite contamination of the same Quaternary sandy material which was also utilized to construct a nearby artificial catchment.

Lignite consists of only dead carbon (free of ${ }^{14} \mathrm{C}$ activity) due to its Tertiary age and on this timescale the comparatively small half-life of $5730 \mathrm{yr}$. Therefore, and as

${ }^{14} \mathrm{C}$ activity measurements allow to study soil organic matter dynamics or to separate OC pools of different age (Trumbore, 2009) we used radiocarbon to clarify if lignite is present in BSCs and substrates (see calculations in Sect. 2.6). Plants and also BSCs maintain a ${ }^{14} \mathrm{C} /{ }^{12} \mathrm{C}$ ratio which is identical to those of the atmospheric $\mathrm{CO}_{2}$ due to the rapid cycling of carbon between the atmosphere and living organisms (Trumbore, 1996). In soil organic matter, radiocarbon determination yields the mean residence time of a mixture of different carbon pools with varying degrees of stability and turnover rates
BGD

$10,851-894,2013$

Biological soil crusts on initial soils

A. Dümig et al.

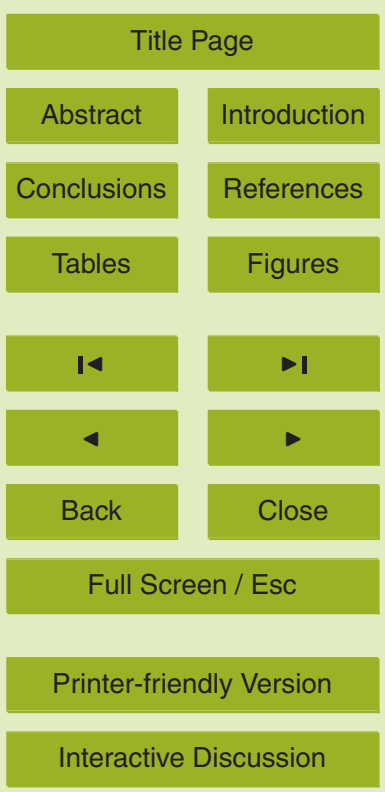


(Trumbore et al., 1989; Scharpenseel and Becker-Heidmann, 1992; von Lützow et al., 2007). In addition, several studies demonstrated that even small amounts of very old $\mathrm{OC}$ can greatly influence the ${ }^{14} \mathrm{C}$ age of soil organic matter (Becker-Heidmann et al., 1988; Paul et al., 1997; Rumpel et al., 1998).

$5 \quad$ As BSCs receive new $C$ inputs via photosynthesis and loose carbon through respiration (Evans and Lange, 2001) the ${ }^{14} \mathrm{C}$ content of the SOC pool of BSCs reflects the balance between $\mathrm{C}$ inputs from net primary productivity of BSC organisms, decomposition rates and radioactive decay (Trumbore, 2000) which makes it difficult to estimate the temporal dimension of BSC dynamics.

10 We would expect that BSCs have high values of pMC $>100(100 \mathrm{pMC}=1950 \mathrm{AD})$ reflecting the incorporation of carbon ("bomb ${ }^{14} \mathrm{C}$ ") fixed from the atmosphere since atomic weapons testing in the early 1960s (Trumbore et al., 1995). Or in other words, high proportions of recent photosynthesis products in BSCs would be indicated by ${ }^{14} \mathrm{C}$ contents which are close to the atmospheric ${ }^{14} \mathrm{CO}_{2}$ level in the year of sampling 15 (105 pMC in 2009; I. Levin, 2012, personal communication). However, the extremely low pMC values at the experimental sand dune (50 to $82 \mathrm{pMC}$, Table 2) showed that $\mathrm{OC}$ in BSCs and above all in substrates has resided long enough for radioactive decay of ${ }^{14} \mathrm{C}$. In consideration of the short-lived metabolism of BSCs and the low soil depth of the substrate material, these very low ${ }^{14} \mathrm{C}$ contents (or old ${ }^{14} \mathrm{C}$ ages of substrates with about 4000-5500 yr BP) are abnormal, and correspond to ${ }^{14} \mathrm{C}$ ages of soil organic matter from various soil types at $100 \mathrm{~cm}$ soil depth (Scharpenseel and Becker-Heidmann, 1997), whereas surface soils usually have a modern ${ }^{14} \mathrm{C}$ signature (Fröberg et al., 2011). At the natural sand dune $(<17 \mathrm{yr}$ old $)$, the ${ }^{14} \mathrm{C}$ contents were clearly higher in BSCs and substrates than at the younger experimental sand dune (Table 2) indicating a lower lignite contribution in fine fractions. This is also reflected by the calculated lignite contents of fine fractions (Table 2).

Thus, ${ }^{14} \mathrm{C}$ contents from fine fractions clearly gave evidence for the contribution of lignite as a SOC source in both sand dunes indicating that $O C$ in BSCs and substrates consists of two pools: recent and rapidly cycling BSC-derived OC and lignite-derived

BGD

$10,851-894,2013$

Biological soil crusts on initial soils

A. Dümig et al.

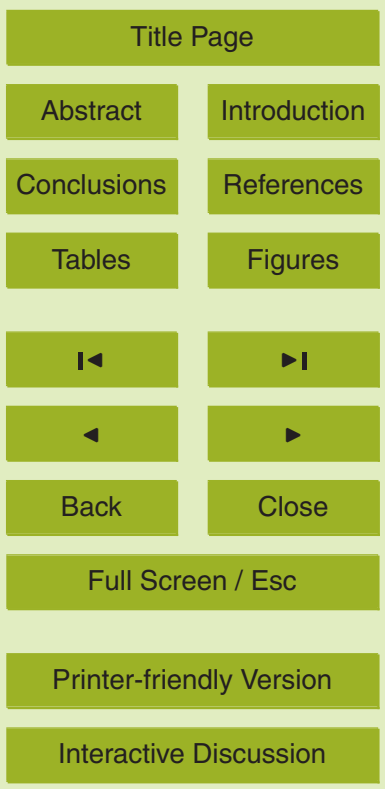


"old" OC (biologically refractory) which is inherited from the parent material at the experimental sand dune and presumably incorporated from atmospheric depositions at both sand dunes.

\subsection{OC fixation in BSC-layers}

5 Our ${ }^{14} \mathrm{C}$ based estimates of the contribution of lignite and BSC allowed us to assess the BSC-derived OC input as the difference in the (lignite-corrected) OC content between $\mathrm{BSC}$ and substrate $\left(\mathrm{OC}_{\mathrm{BSC}}-\mathrm{OC}_{\text {substrate }}\right)$. The $\mathrm{BSC}$-derived $\mathrm{OC}$ inputs for all fine fractions varied between 13 and $57 \mathrm{mg} \mathrm{g}^{-1}$ (Table 3 ) and resulted in increasing pMC values with increasing BSC development indicating a "rejuvenation" of the total OC pool which was more pronounced at the younger experimental dune (Fig. 6). For fine fractions at the natural dune $\left(<17 \mathrm{yr}\right.$ old), the strong correlations between $\mathrm{OC}_{\text {tot }}$ and $\mathrm{pMC}$ values $\left(R^{2}=0.91, p<0.01\right)$ as well as recent OC and pMC values $\left(R^{2}=0.92, p<0.01\right)$ suggest that the total OC pool is controlled by inputs of recent BSC-derived OC. At the experimental dune, no relationships were found between $\mathrm{OC}_{\text {tot }}$ or recent $\mathrm{OC}$ and $\mathrm{pMC}$ 15 values $\left(R^{2}<0.2\right)$, but pMC values were negatively correlated with lignite-C contents $\left(R^{2}=0.82, p<0.05\right)$. Thus, lignite-C still dominated the total OC pool which was in line with the calculated lignite-C contents. Generally, $\mathrm{OC}$ inputs which were calculated without subtraction of lignite were similar to the lignite-corrected values indicating that BSCs and the corresponding substrates showed similar lignite contents.

20 Our estimation of BSC-derived input of OC showed an increasing input with an increasing BSC development and was particularly pronounced for moss-dominated BSCs (Fig. 2) and increased with growing thickness of BSCs. This is in line with findings from other studies (Kidron et al., 2010; Chamizo et al., 2012). Fischer et al. (2010a) found early stages of crust development comprising cyanobacteria and green algae three years after construction of an artificial catchment with BSC-derived OC inputs of about $3.2 \mathrm{mg} \mathrm{g}^{-1}$. At the experimental sand dune which is close to this catchment different BSC-types developed within only four years. Here, algae-dominated BSCs showed
BGD

10, 851-894, 2013

Biological soil crusts on initial soils

A. Dümig et al.

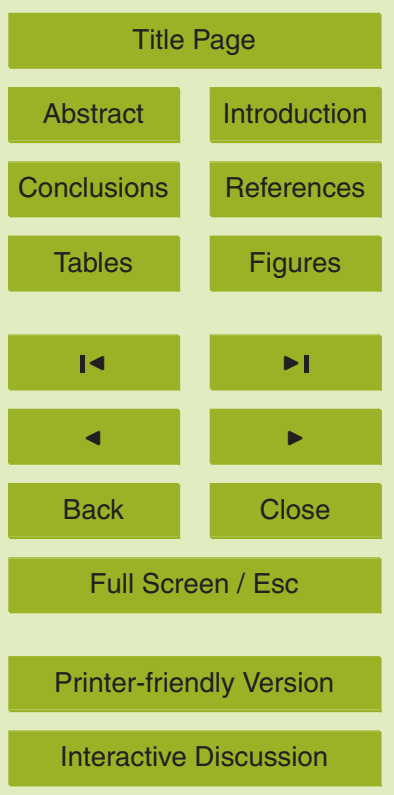

Interactive Discussion 
comparable OC inputs of $1.7-2.7 \mathrm{mgg}^{-1}$, whereas slightly lower values were obtained for algae-dominated BSCs at the natural sand dune $\left(0.8-2.0 \mathrm{mgg}^{-1}\right)$.

Generally, it has to be considered that the net contribution of BSCs to the SOM pool is difficult to assess as net photosynthesis takes place for only short periods 5 after sufficient surface wetting due to rain or dewfall events, whereas carbon losses through respiration can be large during other periods (Lange et al., 1970; Evans and Johansen, 1999; Veste et al., 2001b). So far, determinations of OC inputs by BSCs were predominantly based on laboratory experiments or on the extrapolation of shorter measurement periods from field studies. These studies estimated annual OC inputs 10 in the BSC layer to be $0.4-2.3 \mathrm{~g} \mathrm{C} \mathrm{m}^{-2} \mathrm{a}^{-1}$ for cyanobacterially dominated crusts and 12-37 $\mathrm{g} \mathrm{Cm}^{-2} \mathrm{a}^{-1}$ for lichen- or moss-dominated crusts (Beymer and Klopatek, 1991; Klopatek, 1992; Jeffries et al., 1993; Evans and Lange, 2001). Elbert et al. (2009) give a range from 0.8 to $74.9 \mathrm{~g} \mathrm{Cm}^{-2} \mathrm{a}^{-1}$ for biological soil crusts from arid zones. In our study, we calculated total OC inputs of green algae- $\left(3.1-9.3 \mathrm{~g} \mathrm{~m}^{-2}\right)$ and moss5 dominated BSCs (28.9-87.5 $\mathrm{g} \mathrm{m}^{-2}$ ) after four (experimental sand dune) or seventeen (natural sand dune) years, respectively. In consideration of the assumed maximum age of BSC establishment the annual OC inputs into the soil surface were in the range of the above mentioned values from the literature with $0.2-2.2 \mathrm{~g} \mathrm{~m}^{-2} \mathrm{a}^{-1}$ for algae- and 2.7-21.9 $\mathrm{g} \mathrm{m}^{-2} \mathrm{a}^{-1}$ for moss-dominated BSCs.

\subsection{OC composition of BSCs}

The comparison of ${ }^{13} \mathrm{C}$ NMR spectra from fractions $<63 \mu \mathrm{m}$ between BSC-layers and the corresponding substrates revealed that BSC colonization on both sand dunes mainly resulted in accumulation of O-alkyl C, alkyl C and N-alkyl C (Fig. 3). Thus, BSCderived input of $\mathrm{OC}$ into soil comprised polysaccharides, aliphatic biopolymers and proteinaceous compounds (Wilson et al., 1983; Duncan, 1987; Kögel-Knabner, 1997). This is in line with the general composition of microbial materials and BSC-produced extracellular polymeric substances (Baldock et al., 1990; Kögel-Knabner et al., 1992;
BGD

$10,851-894,2013$

Biological soil crusts on initial soils

A. Dümig et al.

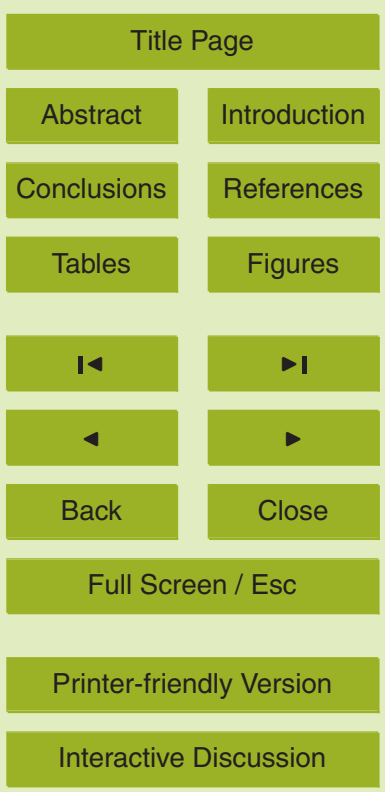


Nierop et al., 2001; Flemming and Wingender, 2010). Increasing carbohydrate and protein contents were also found by other studies investigating successional stages of BSC development (Mazor et al., 1996; Kidron et al., 2010; Zaady et al., 2010). Consistent differences in the chemical composition between algae-dominated BSCs and 5 BSCs with mosses were not detected at both sand dunes.

As shown in Fig. 3, BSC-derived OC diminished the relative proportions of aromatic carbon species which can be related to lignite. As Lusatian lignite represents one of the earliest stages of coalification with low aromaticity (Stach et al., 1982; Rumpel et al., 1998), the BSC and substrate samples show relatively low proportions of aro10 matic $\mathrm{C}$, very likely reflecting contamination with brown coal. Besides of aromatic carbon, aliphatic carbon species are characteristic structures for coalification processes (Hatcher et al., 1989). As absolute lignite contents were similar between BSCs and substrates and lignite-C in \% of $\mathrm{OC}_{\text {tot }}$ was markedly higher in substrates, only small proportions of alkyl $\mathrm{C}$ may also originate from lignite contribution.

${ }_{15}$ Findings from ${ }^{13} \mathrm{C}$ NMR spectra were confirmed by analysis of sugar monomers from bulk materials where we observed increasing contents of carbohydrate- $C$ with increasing thickness of BSCs as well as from algae-dominated BSCs to BSCs with mosses (Fig. 4). Almost $70 \%$ of total OC was carbohydrate-C in moss-dominated BSCs at the natural sand dune. Similarly high carbohydrate-C contents (up to $75 \%$ of the total SOC) were reported from cyanobacterial soil crusts in the Kalahari (Mager, 2010). The growing proportion of carbohydrate-C on $\mathrm{OC}_{\text {tot }}$ with increasing $\mathrm{OC}$ content in form of a saturation curve is shown in Fig. 5 indicating the predominant accumulation of carbohydrates during BSC development from algae- to moss-dominated BSCs.

The frequently applied ratio of galactose plus mannose over arabinose plus xylose (GM/AX) from Oades (1984) which is indicative for plant-derived carbohydrates $(<0.5)$ or microbial carbohydrates $(>2.0)$ show that carbohydrates from all measured materials (BSC bulk materials and fractions $<63 \mu \mathrm{m}$ from BSCs and substrates) from both sand dunes mainly derived from microbial synthesis. However, mosses which do not excrete exopolysaccharides (Harper and Marble, 1988) show also high GM/AX ratios
BGD

$10,851-894,2013$

\section{Biological soil crusts} on initial soils
A. Dümig et al.

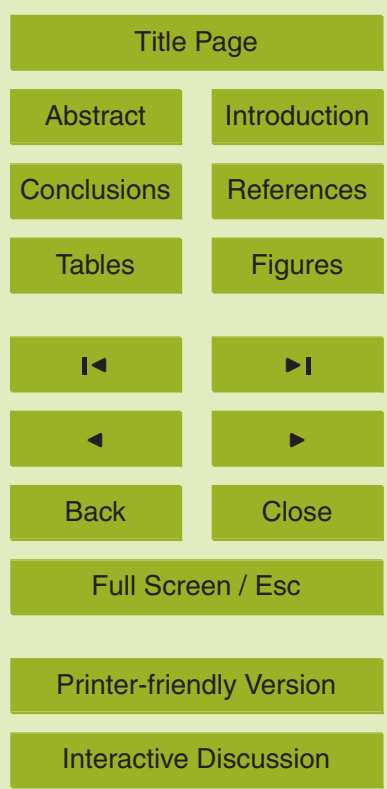


larger than 2.0 (Nierop et al., 2001; Prietzel et al., 2012) due to high proportions of galactose, mannose and rhamnose in the hemicellulose of the primary cell wall (Popper and Fry, 2003). This makes it impossible to differentiate between algae- and mossderived carbohydrates. The lowest GM/AX ratio (1.7) was found for algae-dominated 5 BSCs (ND3) in the vicinity of the grass Corynephorus canescens (GM/AX of 0.1 for leaves and 0.3 for roots; Nierop et al., 2001) at the natural sand dune. At the experimental sand dune the lowest GM/AX ratio (2.9) was found for BSCs with the lowest thickness of mosses between dense grass cover (ED3). This may point to some input of grass-derived OC.

\subsection{OC accumulation in substrates beneath the BSC-layer: Is there depth translocation of BSC-derived OC?}

At the experimental sand dune $(<4 \mathrm{yr}$ old), the OC contents of the substrates were similar between the different BSC types (bulk materials and fine fractions), but OC content of BSCs increased from algae-dominated to moss-dominated BSCs (Table 1).

This suggests that no translocation of OC occurred into greater soil depth. Similarly, $\mathrm{OC}$ contents gave no indications for $\mathrm{OC}$ depth translocation of algae-dominated BSCs at the natural sand dune. For moss-dominated BSCs at the natural sand dune with a maximum age of $17 \mathrm{yr}$ (ND4, 5), considerably larger OC contents (bulk materials and fine fractions) of both, crust materials and the corresponding substrates point to the presence of BSC-derived OC up to three $\mathrm{cm}$ soil depth.

At the moss-dominated BSCs from the natural sand dune (ND4, 5), a downward translocation of $\mathrm{OC}$ from the crust into the substrate below the crust was also demonstrated by ${ }^{14} \mathrm{C}$ contents (Table 2). In contrast to the experimental sand dune as well as the mobile sand and algae-dominated BSCS at the ND, increased ${ }^{14} \mathrm{C}$ contents were
BGD

$10,851-894,2013$

Biological soil crusts on initial soils
A. Dümig et al.

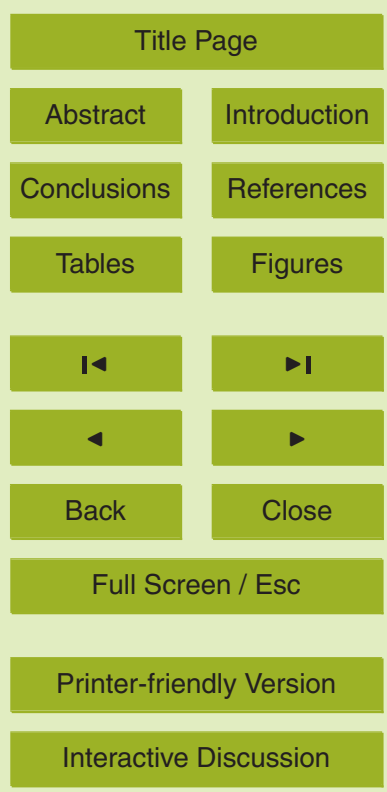


So far, only one study investigated the potential contribution of BSCs to OC accumulation in soils beneath the BSCs by using a ${ }^{14} \mathrm{CO}_{2}$ chamber experiment (Beymer and Klopatek, 1991). In this study, a downward translocation of photosynthate was indicated by an increase in ${ }^{14} \mathrm{C}$ content in the soils beneath the crusts which was acribed 5 to leaching of BSC-derived carbohydrates. There is no indication that crust organisms tend to migrate into greater soil depth (Brock, 1975). Increased infiltrability which promotes the downward leaching of $\mathrm{OC}$ is maybe a result of the channeling effect of the moss stems and rhizoids (Kidron et al., 2010).

Depth translocation of $\mathrm{OC}$ by leaching presupposes water soluble organic sub10 stances. Fine fractions $<63 \mu \mathrm{m}$ were obtained by wet sieving and thus, comprising clay- and silt-associated $\mathrm{OC}$ and water-soluble $\mathrm{OC}$ of the sand fraction. Despite of very low clay and silt contents (Table 1), fine fractions represented 10-48 and 33-48\% OC (mass-\% of total OC) of bulk materials from BSCs and substrates, respectively. In addition, higher OC contents (mass-\% of total OC) were found for substrates when 15 compared to BSCs and for the natural when compared to the experimental sand dune (data not shown). Figure 7 compares the OC contents between bulk materials and fractions $<63 \mu \mathrm{m}$ which shows a clear difference between both sand dunes. At the natural sand dune there was a concurrent $\mathrm{OC}$ increase of both, bulk materials and fractions $<63 \mu \mathrm{m}$. In contrast, differences in the OC content between BSC types at the experimental sand dune were almost only detectable for bulk materials. This indicated that $\mathrm{OC}$ in BSC bulk materials from the experimental sand dune is less water-soluble than that of the natural sand dune. As shown in Fig. 4, similar differences between both sand dunes with respect to water solubility were found for carbohydrates. The comparison of carbohydrate contents between BSC bulk materials and BSC fractions $<63 \mu \mathrm{m}$ demonstrated that carbohydrates from the natural sand dune were more water-soluble than those of the experimental sand dune. There, the carbohydrate-C content of fractions $<63 \mu \mathrm{m}$ from BSCs were much lower than those of BSC bulk materials and similarly high as those from the substrates (fractions $<63 \mu \mathrm{m}$ ) indicating a low water solubility of carbohydrates.

\section{BGD}

$10,851-894,2013$

\section{Biological soil crusts on initial soils}

A. Dümig et al.

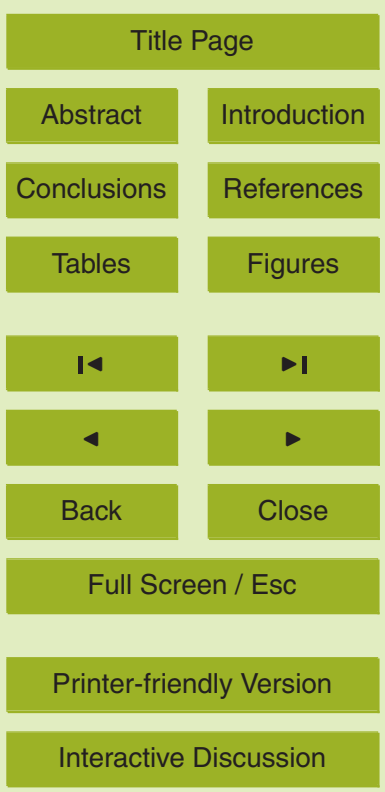

Interactive Discussion 
BSCs at the experimental sand dune accumulated less O-alkyl C, but also alkyl C when compared to the natural sand dune (Fig. 3). Bacteria and algae excrete extracellular polymeric substances (Bertocchi et al., 1990; Terauchi and Kondo, 2008; Flemming and Wingender, 2010), and the different nature of microbial exudates may point to 5 differences between both sand dunes in terms of the composition of the BSC communities, temperature, availablity of nutrients or the experienced shear forces (Flemming and Wingender, 2010). The accumulation of alkyl $\mathrm{C}$ which mainly comprises aliphatic biopolymers in microbial exudates of BSCs may is responsible for the lower water solubility of extracellular polymeric substances at the experimental sand dune. Generally, 10 the effect of BSC-derived extracellular polymeric substances on hydrological properties of the soil surface like water infiltration or run-off is still controversial (Eldridge, 2003; Rossi et al., 2012) which may result from different chemical compositions of the BSC-derived OC input.

Finally, OC accumulation in the substrate beneath moss-dominated BSCs at the 15 natural sand dune may result in accelerated soil formation due to increased mineral weathering (Amit and Harrison, 1995; Drever and Stillings, 1997; Chen et al., 2009).

\subsection{Implications for the temporal establishment and development of BSCs}

Information about the temporal establishment of BSCs are generally reported as recovery times of BSCs after disturbance and range from decades to centuries depend20 ing on crust and soil type, extent of disturbance, the presence of vascular plants, and climate conditions as summarized by Evans and Johansen (1999), Belnap and Eldridge (2003) and Maestre et al. (2011). In this regard, cyanobacteria re-establish faster than lichens and bryophytes (Anderson et al., 1982; Belnap and Gillette, 1997). Much faster successions of BSCs after experimental disturbance were found in a semi-

desert in South Africa where cyanobacteria-dominated BSCs recolonized small-scale disturbances of the soil surface already after 8 month and bryophytes were observed after 20 month (Dojani et al., 2011) as similar to sand dunes in the Negev desert (Veste et al., 2001a). At the experimental sand dune, algae- and moss-dominated BSC-types
BGD

$10,851-894,2013$

Biological soil crusts on initial soils

A. Dümig et al.

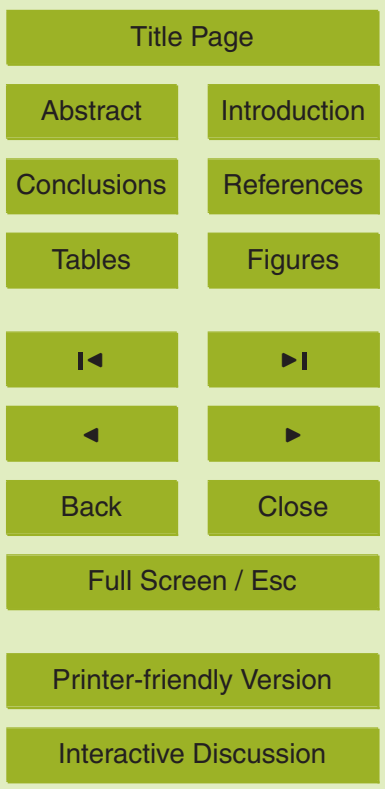

Interactive Discussion 
has been established within only $4 \mathrm{yr}$ indicating rapid BSC development and succession from algae- to moss-dominated BSCs in a temperate climate. Similar BSC types were found at the natural sand dune with a maximum age of $17 \mathrm{yr}$.

Because of the presence of lignite, it can be hypothesized that the younger the ${ }^{14} \mathrm{C}$ 5 age (the higher the pMC) of OC in BSCs, the higher is the BSC-derived OC accumulation due to longer existence of the BSC on the substrate and/or higher net $\mathrm{C}$ uptake rates of the BSC. Following this assumption, then moss-dominated BSCs are the oldest and most stable BSCs at the natural sand dune (Table 2). In consideration that mossdominated BSCs were established at the experimental sand dune already after $4 \mathrm{yr}$, 10 the further development of algae- to moss-dominated BSCs cannot be expected at the natural sand dune $(<17 \mathrm{yr}$ old) under the present environmental conditions. Here, the distribution of BSC types is presumably rather controlled by surface stability as shear stress by wind which is highest on the top of the sand dune and decreases along the lee slope (Kroy et al., 2002). According to this spatial sequence we found the change 15 from mobile sand to algae-dominated BSCs and to moss-dominated BSCs. This BSC distribution at the natural sand dune may represent a steady-state under the present environmental conditions. A high correlation between BSC cover, micro-topography, wind power and surface wetness was also reported for arid sand dunes (Veste and Littmann, 2006; Kidron et al., 2009; Veste et al., 2011).

The evaluation of the temporal BSC establishment at the experimental sand dune is more intricate due to the higher variability of lignite contamination, and thus also ${ }^{14} \mathrm{C}$ contents (Table 2). However, moss-dominated BSCs showed the same trend of increasing ${ }^{14} \mathrm{C}$ contents in dependence of the position in the slope: footslope > backslope $>$ crest. Thus, this sequence may also reflect the duration of BSC colonization of the soil surface. As similar to the natural sand dune, the backslope and above all the footslope are more stable against wind-induced redistribution of sand particles at the soil surface which may promote BSC development when compared to the position on the crest. In addition, at the base of the slope more moisture is available which may
BGD

$10,851-894,2013$

\section{Biological soil crusts on initial soils}
A. Dümig et al.

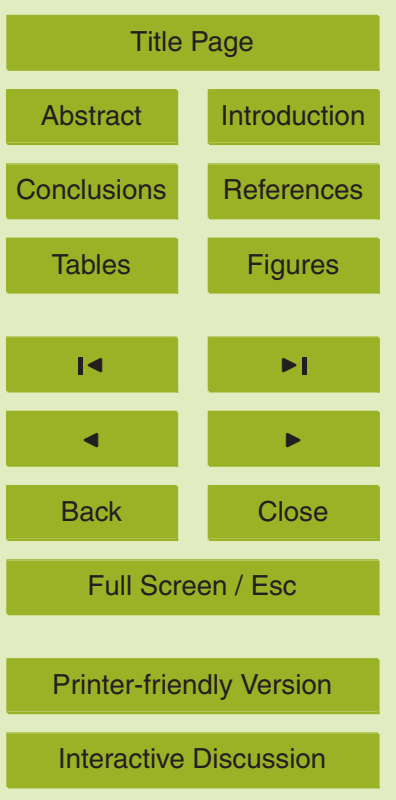


result in higher productivity of BSCs at the footslope (Belnap et al., 2004; Veste and Littmann, 2006), and thus in higher accumulation rate of $O C$ and higher ${ }^{14} \mathrm{C}$ contents.

Another factor which may influence the formation of BSCs at both sand dunes is the occurrence of grasses as moss-dominated BSCs were only found in the proximate 5 vicinity of grasses. However, ambiguous results are reported for the role of vascular plants on BSC development and vice versa (Eldridge and Greene, 1994). On the one hand, vascular plants may displace BSCs as they are more effective in the competition on light, nutrients and water (Löbel et al., 2006). Otherwise, BSC development can be promoted in the vicinity of vascular plants due to increased soil organic matter, nutri10 ents and fertility (Ingerpuu et al., 2005; Zhao et al., 2010) or increased surface stability due to root penetration. Our results give no evidence that soil properties influenced BSC distribution on both sand dunes. However, BSCs showed slightly higher Fe concentrations and portions of fine fractions $<63 \mu \mathrm{m}$ compared to the substrate. This may result from deposition due to the trapping of sediment by BSC organisms (Reynolds 15 et al., 2001) as weathering of silicates cannot be expected in view of the young age of both sand dunes (Fischer et al., 2010a).

\section{Conclusions}

Our results show a rapid BSC establishment and development from algae- to mossdominated BSCs in this temperate climate with different BSC-types (algae- and moss-

dominated BSCs) developing within only $4 \mathrm{yr}$. The main factor influencing the distribution of BSC types was presumably the surface stability according to the position in the slope. We found no evidence that soil properties affected the BSC distribution on both sand dunes.

${ }^{14} \mathrm{C}$ contents indicated that total OC in BSCs and substrates consisted of two pools: 25 recent BSC-derived OC and lignite-derived "old" OC (biologically refractory) which is inherited from the parent material and/or incorporated from atmospheric depositions. Mean ${ }^{14} \mathrm{C}$ residence time of total SOC in BSC-layers and substrates decreased

\section{BGD}

$10,851-894,2013$

\section{Biological soil crusts} on initial soils
A. Dümig et al.

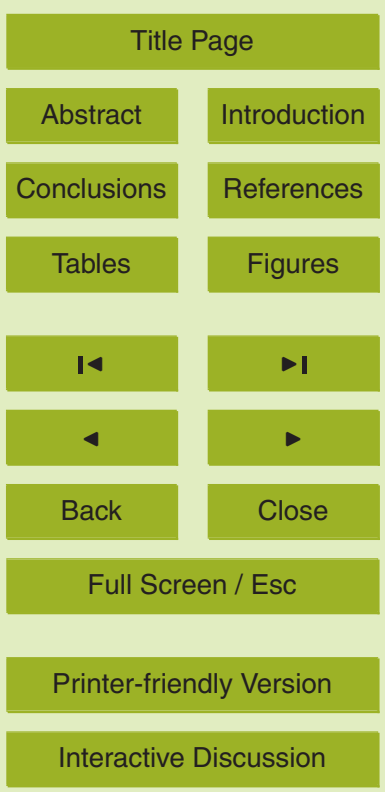


significantly with BSC development and increasing input rates of recent BSC-derived OC. Our results suggest that moss-dominated BSCs have the potential to accelerate soil formation as their underlying substrate at the natural dune had increased contents of $\mathrm{OC}$ and carbohydrate-C as well as higher ${ }^{14} \mathrm{C}$ contents due to downward transloca5 tion of OC.

BSC-derived OC mainly comprised O-alkyl C (carbohydrate-C) and to a lesser extent also alkyl $\mathrm{C}$ and $\mathrm{N}$-alkyl $\mathrm{C}$ in varying compositions. The accumulation of alkyl $\mathrm{C}$ in BSCs at the experimental dune may have induced the lower water solubility of OC and carbohydrate-C when compared to BSCS at the natural sand dune without alkyl 10 C accumulation. This was shown by the comparison between bulk materials and fractions $<63 \mu \mathrm{m}$ indicating that hydrological effects of BSCs on soils like water repellency and infiltration depend on the chemical composition of the extracellular polymeric substances.

Acknowledgement. This study is part of the Transregional Collaborative Research Centre 38 15 (SFB/TRR 38) which is financially supported by the Deutsche Forschungsgemeinschaft (DFG, Bonn) and the Brandenburg Ministry of Science, Research and Culture (MWFK, Potsdam). We are grateful to I. Hajdas (ETH Zürich) for measuring radiocarbon and to I. Levin and B. Kromer for the provision of atmospheric ${ }^{14} \mathrm{CO}_{2}$ values.

\section{References}

Amelung, W., Cheshire, M. V., and Guggenberger, G.: Determination of neutral and acidic sugars in soil by capillary gas-liquid chromatography after trifluoroacetic acid hydrolysis, Soil Biol. Biochem., 28, 1631-1639, 1996.

Amit, R. and Harrison, J. B. J.: Biogenic calcic horizon development under extremely arid conditions, Nizzana sand dunes, Israel, Adv. GeoEcol., 28, 65-88, 1995.

25 Anderson, D. C., Harper, K. T., and Holmgren, R. C.: Recovery of cryptogamic soil crusts from grazing on Utah winter ranges, J. Range Man., 35, 355-359, 1982.
BGD

10, 851-894, 2013

\section{Biological soil crusts} on initial soils
A. Dümig et al.

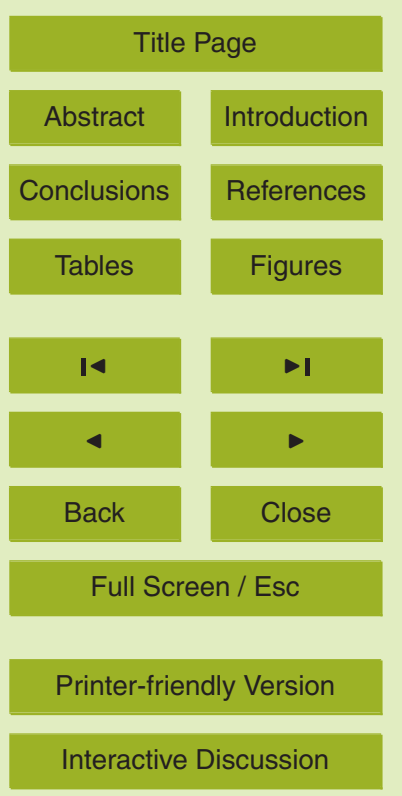


Baldock, J. A., Oades, J. M., Vassallo, A. M., and Wilson, M. A.: Solid-state CP/MAS ${ }^{13}$ C NMR analysis of bacterial and fungal cultures isolated from a soil incubated with glucose, Aust. J. Soil Res., 28, 213-225, 1990.

Becker-Heidmann, P., Liang-Wu, L., and Scharpenseel, H. W.: Radiocarbon dating of organic 5 matter fractions of a Chinese mollisol, Z. Pflanzenernähr. Bodenk., 151, 37-39, 1988.

Belnap, J.: Nitrogen fixation in biological soil crusts from southeast Utah, USA, Biol. Fert. Soils, 35, 128-135, 2002.

Belnap, J.: The potential roles of biological soil crusts in dryland hydrological cycles, Hydrol. Process., 20, 3159-3178, 2006.

10 Belnap, J. and Eldridge, D.: Disturbance and recovery of biological soil crusts, in: Biological Soil Crusts: Structure, Function, and Management, edited by: Belnap, J. and Lange, O. L., Springer-Verlag Berlin, Heidelberg, 363-383, 2003.

Belnap, J. and Gardner, J. S.: Soil microstructure in soils of the Colorado Plateau: the role of the cyanobacterium Microcoleus vaginatus, Great Basin Nat., 53, 40-47, 1993.

15 Belnap, J. and Gillette, D. A.: Disturbance of biological soil crusts: impacts on potential wind erodibility of sandy desert soils in Southeastern Utah, Land Degrad. Develop., 8, 355-362, 1997.

Belnap, J. and Lange, O. L.: Biological Soil Crusts: Structure, Function and Management, Ecological Studies 150, Springer, Berlin, 2001.

Belnap, J., Phillips, S. L., and Miller, M. E.: Response of desert biological soil crusts to alterations in precipitation frequency, Oecolgia, 141, 306-316, 2004.

Bertocchi, C., Navarini, L., Cesáro, A., and Anastasio, M.: Polysaccharides from cyanobacteria, Carbohydr. Polym., 12, 127-153, 1990.

Beymer, R. J. and Klopatek, J. M.: Potential contribution of carbon by microphytic crusts in Pinyon-Juniper Woodlands, Arid Soil Res. Rehab., 5, 187-198, 1991.

Beyschlag, W., Wittmann, M., Jentsch, A., and Steinlein, T.: Soil crusts and disturbance benefit plant germination, establishment and growth on nutrient deficient sand, Basic Appl. Ecol., 9, 243-252, 2008.

Brankatschk, R., Fischer, T., Veste, M., and Zeyer, J.: Succession of $\mathrm{N}$ cycling processes in biological soil crusts on a Central European inland dune, FEMS Microbiol Ecol., 83, 149160, doi:10.1111/j.1574-6941.2012.01459.x, 2012.

Brock, T. D.: Effect of water potential on a Microcoleus (Cyanophydeae) from a desert crust, J. Phycol., 11, 316-320, 1975.
BGD

$10,851-894,2013$

Biological soil crusts on initial soils

A. Dümig et al.

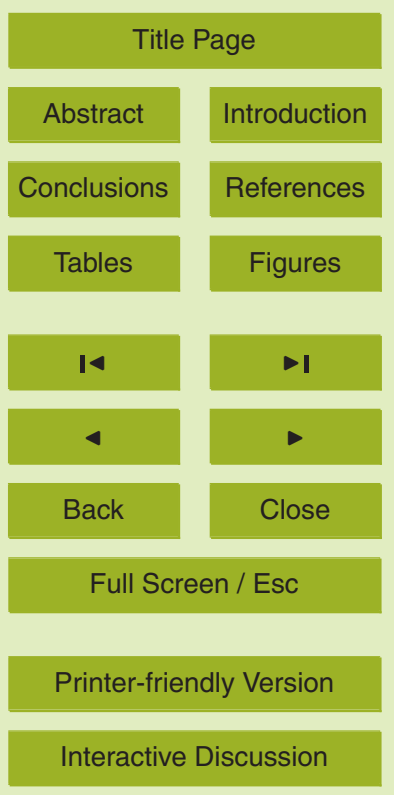


Bronk Ramsey, C.: Development of the radiocarbon program OxCal, Radiocarbon, 43, 355363, 2001.

Castillo-Monroy, A. P., Bowker, M. A., Maestre, F. T., Rodríguez-Echeverría, S., Martínez, I., Barraza-Zepeda, C. E., and Escolar, C.: Relationships between biological soil crusts, bacte5 rial diversity and abundance, and ecosystem functioning: insights from a semi-arid Mediterranean environment, J. Vegetat. Sci., 22, 165-174, 2001.

Chamizo, S., Cantón, Y., Miralles, I., and Domingo, F.: Biological soil crust development affects physicochemical characteristics of soil surface in semiarid ecosystems, Soil Biol. Biochem., 49, 96-105, 2012.

10 Chen, R., Zhang, Y., Li, Y., Wei, W., Zhang, J., and Wu, N.: The variation of morphological features and mineralogical components of biological soil crusts in the Gurbantunggut Desert of Northwestern China, Environ. Geol., 57, 1135-1143, 2009.

Dojani, S., Büdel, B., Deutschewitz, K., and Weber, B.: Rapid succession of biological soil crusts after experimental disturbance in the Succulent Karoo, South Africa, Appl. Soil Ecol., 48, 263-269, 2011.

Drever, J. I. and Stillings, L. L.: The role of organic acids in mineral weathering, Colloid. Surf. A: Physicochem. Eng. Asp., 120, 167-181, 1997.

Duncan, T. M.: ${ }^{13} \mathrm{C}$ chemical shielding in solids, J. Phys. Chem. Ref. Data, 16, 125-151, 1987.

Eder, E., Spielvogel, S., Kölbl, A., Albert, G., and Kögel-Knabner, I.: Analysis of hydrolysable neutral sugars in mineral soils: improvement of alditol acetylation for gas chromatographic separation and measurement, Org. Geochem., 41, 580-585, 2010.

Elbert, W., Weber, B., Büdel, B., Andreae, M. O., and Pöschl, U.: Microbiotic crusts on soil, rock and plants: neglected major players in the global cycles of carbon and nitrogen?, Biogeosciences Discuss., 6, 6983-7015, doi:10.5194/bgd-6-6983-2009, 2009.

Elbert, W., Weber, B., Burrow, S., Steinkamp, J., Büdel, B., Andreae, M. O., and Pöschl, U.: Contribution of cryptogamic covers to the global cycles of carbon and nitrogen, Nat. Geosci., 5, 459-462, 2012.

Eldridge, D. J.: Biological soil crusts and water relations in Australia deserts, in: Biological Soil Crusts: Structure, Function and Management, edited by: Belnap, J. and Lange, O. L., Springer, Berlin, 315-325, 2003.

Eldridge, D. J., and Greene, R. S. B.: Microbiotic soil crusts: a review of their roles in soil and ecological processes in the rangelands of Australia, Aust. J. Soil Res., 32, 389-415, 1994.
BGD

10, 851-894, 2013

\section{Biological soil crusts on initial soils}

A. Dümig et al.

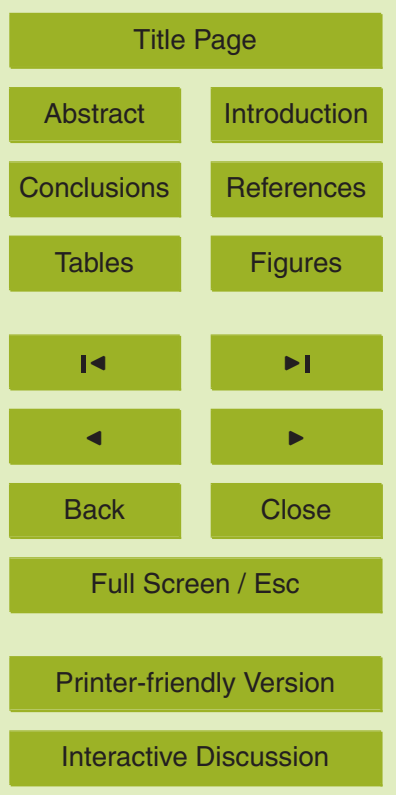


Evans, R. D. and Johansen, J. R.: Microbiotic crusts and ecosystem processes, Crit. Rev. Plant Sci., 18, 183-225, 1999.

Evans, R. D. and Lange, O. L.: Biological soil crusts and ecosystem nitrogen and carbon dynamics, in: Biological Soil Crusts: Structure, Function and Management, edited by: Belnap, J. and Lange, O. L., Springer-Verlag, Berlin, 2003.

Fischer, T., Veste, M., Schaaf, W., Dümig, A., Kögel-Knabner, I., Wiehe, W., Bens, O., and Hüttl, R. F.: Initial pedogenesis in a topsoil crust 3 years after construction of an artificial catchment in Brandenburg, NE Germany, Biogeochemistry, 101, 165-176, 2010a.

Fischer, T., Veste, M., Wiehe, W., and Lange, P.: Water repellency and pore clogging at early successional stages of biological soil crusts on inland dunes, Brandenburg, NE Germany, Catena, 80, 47-52, 2010b.

Fischer, T., Veste, M., Eisele, A., Bens, O., Spyra, W., and Hüttl, R. F.: Small scale spatial heterogeneity of normalized difference vegetation indices (NDVI) and hot spots of photosynthesis in biological soil crusts, Flora, 207, 159-167, 2012.

15 Flemming, H.-C. and Wingender, J.: The biofilm matrix, Nat. Rev. Microbiol., 8, 623-633, 2010.

Fröberg, M., Tipping, E., Stendahl, J., Clarke, N., and Bryant, Ch.: Mean residence time of $O$ horizon carbon along a climatic gradient in Scandinavia estimated by ${ }^{14} \mathrm{C}$ measurements of archived soils, Biogeochemistry, 104, 227-236, 2011.

Harper, K. T. and Marble, J. R.: A role for nonvascular plants in management of arid and semiarid rangelands, in: Applications of Plant Sciences to Rangeland Management and Inventory, edited by: Tuller, P. T., Kluwer, Amsterdam, 135-169, 1988.

Hatcher, P. G., Wilson, M. A., Vasallo, A. M., and Lerch, H. E.: Studies of angiospermous woods in Australian brown coals by nuclear magnetic resonance and analytical pyrolysis: new insights into early coalification, Int. J. Coal Geol., 13, 99-126, 1989.

25 Ingerpuu, N., Liira, J., and Pärtel, M.: Vascular plants facilitated bryophytes in a grassland experiment, Plant Ecol., 180, 69-75, 2005.

Jeffries, D. L., Link, S. O., and Klopatek, J. M.: $\mathrm{CO}_{2}$ fluxes of cryptogamic crusts. I. response to resaturation, New Phytol., 125, 163-173, 1993.

Jentsch, A. and Beyschlag, W.: Vegetation ecology of dry acidic grasslands in the lowland area of central Europe, Flora, 189, 3-26, 2003.

Kidron, G. J., Vonshak, A., and Abeliovich, A.: Microbiotic crusts as biomarkers for surface stability and wetness duration in the Negev Desert, Earth Surf. Process. Landf., 34, 15941604, 2009.

\section{BGD}

10, 851-894, 2013

\section{Biological soil crusts on initial soils}
A. Dümig et al.

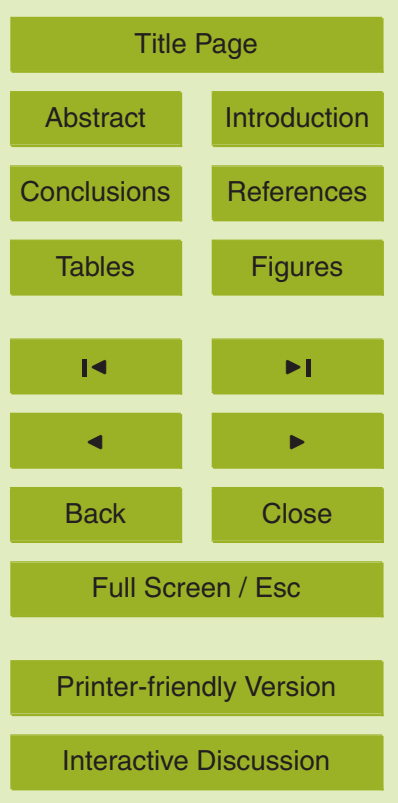


Kidron, G. J., Vonshak, A., Dor, I., Barinova, S., and Abeliovich, A.: Properties and spatial distribution of microbiotic crusts in the Negev Desert, Israel, Catena, 82, 92-101, 2010.

Klouda, B., Lewis, C. W., Rasmussen, R. A., Rhoderick, G. C., Sams, R. L., Stevens, R. K., Currie, L. A., Donahue, D. J., Jull, T. A. J., and Seila, R. L.: Radiocarbon measurements of 5 atmospheric volatile organic compounds: quantifying the biogenic contribution, Environ. Sci. Technol., 30, 1098-1105, 1996.

Knicker, H. and Lüdemann, H-D.: N-15 and C-13 CPMAS and solution NMR studies of N-15 enriched plant material during 600 days of microbial degradation, Org. Geochem., 23, 329341, 1995.

10

Kögel-Knabner, I.: ${ }^{13} \mathrm{C}$ and ${ }^{15} \mathrm{~N}$ NMR spectroscopy as a tool in soil organic matter studies, Geoderma, 80, 243-270, 1997.

Kögel-Knabner, I., Hatcher, P. G., Tegelaar, E. W., and De Leeuw, J. W.: Aliphatic components of forest soil organic matter as determined by solid-state ${ }^{13} \mathrm{C}$ NMR and analytical pyrolysis, Sci. Total Environ., 113, 89-106, 1992.

Kroy, K., Sauermann, G., and Herrmann, H. J.: Minimal model for sand dunes, Phys. Rev. Lett., 88, 1- 4, 2002.

Lange, O. L., Kidron, G., Büdel, B., Meyer, A., Kilian, E., and Abeliovich, A.: Taxonomic composition and photosynthetic characteristics of the "biological soil crusts" covering sand dunes in the western Negev Desert, Funct. Ecol., 6, 519-527, 1992.

20 Lange, O. L., Belnap, J., Reichenberger, H., and Meyer, A.: Photosynthesis of green algal soil crust lichens from arid lands in southern Utah, USA: role of water content on light and temperature response of $\mathrm{CO}_{2}$ exchange, Flora, 192, 1-15, 1997.

Langhans, T. M., Storm, C., and Schwabe, A.: Community assembly of biological soil crusts of different successional stages in a temperate sand ecosystem, as assessed by direct determination and enrichment techniques, Microbial Ecol., 58, 394-407, 2009.

Lázaro, R., Cantón, Y., Solé-Benet, A., Bevan, J., Alexander, R., Sancho, L. G., and Puigdefábregas, J.: The influence of competition between lichen colonization and erosion on the evolution of soil surfaces in the Tabernas badlands (SE Spain) and its landscape effect, Geomorphology, 102, 252-266, 2008.

30 Levin, I. and Kromer, B.: The tropospheric ${ }^{14} \mathrm{CO}_{2}$ level in mid-latitudes of the Northern Hemisphere (1959-2003), Radiocarbon, 46, 1261-1272, 2004.

\section{BGD}

$10,851-894,2013$

\section{Biological soil crusts} on initial soils
A. Dümig et al.

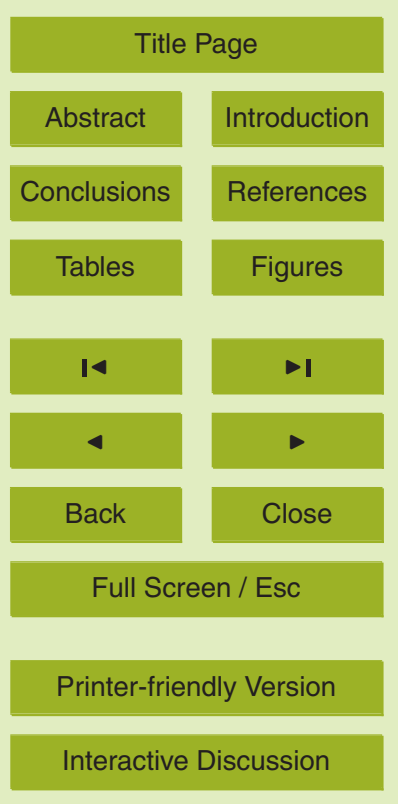


Löbel, S., Dengler, J., and Hobohm, C.: Species richness of vascular plants, bryophytes and lichens in dry grasslands: the effects of environment, landscape structure and competition, Folia Geobot., 41, 377-393, 2006.

Maestre, F. T., Huesca, M. T., Zaady, E., Bautista, S., and Cortina, J.: Infiltration, penetration 5 resistance and microphytic crust composition in contrasted microsites within a Mediterranean semi-arid steppe, Soil Biol. Biochem., 34, 895-898, 2002.

Maestre, F. T., Bowker, M. A., Cantón, Y., Castillo-Monroy, A. P., Cortina, J., Escolar, C., Escudero, A., Lázaro, R., and Martínez, l.: Ecology and functional roles of biological soil crusts in semi-arid ecosystems of Spain, J. Arid Environ., 75, 1282-1291, 2011.

10 Mager, D.: Carbohydrates in cyanobacterial soil crusts as a source of carbon in the southwest Kalahari, Botswana, Soil Biol Biochem. 42, 313-318, 2010.

Mazor, G., Kidron, G. J., Vanshak, A., and Abeliovich, A.: The role of cyanobacterial exopolysaccharides in structuring desert microbial crusts, FEMS Microbiol. Ecol., 21, 121-130, 1996.

Mehra, O. P. and Jackson, M. L.: Iron oxide removal from soils and clays by a dithionite-citrate system buffered with sodium bicarbonate, in: Proceedins of the 7th National Conference on Clays and Clay Minerals, edited by Ingerson, E., Pergamon Press, London, 317-327, 1960.

Nierop, K. G. J., van Lagen, B., and Buurman, P.: Composition of plant tissues and soil organic matter in the first stages of a vegetation succession, Geoderma, 100, 1-24, 2001.

Oades J. M.: Soil organic matter and structural stability: mechanisms and implications for management, Plant Soil, 76, 319-337, 1984.

Paul, E. A., Follett, R. F., Leavitt, S. W., Halvorson, A., Peterson, G. A., and Lyon, D. J.: Radiocarbon dating for determination of soil organic matter pool sizes and dynamics, Soil Sci. Soc. Am. J., 61, 1058-1067, 1997.

Peersen, O. B., Wu, X., Kustanovich, I., and Smith, S. O.: Variable-amplitude cross-polarization MAS NMR, J. Magn. Reson., 104, 334-339, 1993.

Popper, Z. A. and Fry, S. C.: Primary cell wall composition of bryophytes and charophytes, Ann. Bot-London, 91, 1-12, 2003.

Prasse, R. and Bornkamm, R.: Effect of microbiotic soil surface crusts on emergence of vascular plants, Plant Ecol., 150, 65-75, 2000.

30 Prietzel, J., Dechamps, N., and Spielvogel, S.: Analysis of non-cellulosic polysaccharides helps to reveal the history of thick organic surface layers on calcareous Alpine soils, Plant Soil, doi:10.1007/s11104-012-1340-2, 2012.

\section{BGD}

10, 851-894, 2013

\section{Biological soil crusts on initial soils}
A. Dümig et al.

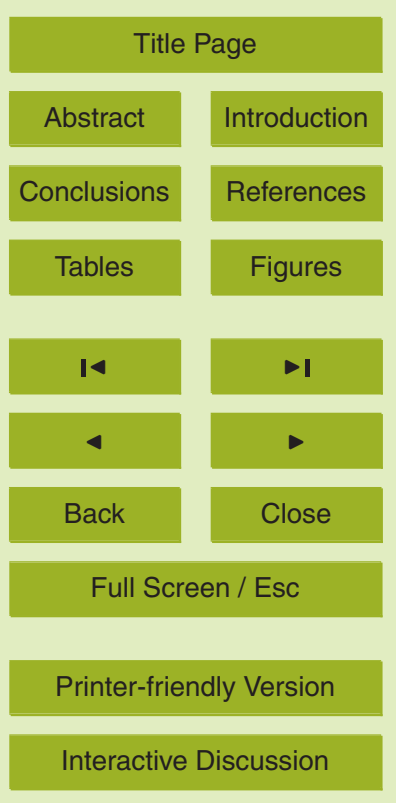


Reynolds, R., Belnap, J., Reheis, M., Lamothe, P., and Luiszer, F.: Aeolian dust in Colorado Plateau soils: nutrient inputs and recent change in source, Proc. Natl. Acad. Sci. USA, 98, 7123-7127, 2001.

Rossi, F., Potrafka, R. M., Pichel, F. G., and De Philippis, R.: The role of the exopolysaccharides 5 in enhancing hydraulic conductivity of biological soil crusts, Soil Biol. Biochem., 46, 33-40, 2012.

Rumpel, C. and Dignac, M.-F.: Gas chromatographic analysis of monosaccharides in a forest soil profile: analysis by gas chromatography after trifluoroacetic acid hydrolysis and reduction-acetylation, Soil Biol. Biochem., 38, 1478-1481, 2006.

10 Rumpel, C., Knicker, H., Kögel-Knabner, I., and Hüttl, R. F.: Airborne contamination of immature soil (Lusatian mining district) by lignite-derived materials: its detection and contribution to the soil organic matter budget, Water Air Soil Pollut., 105, 481-492, 1998.

Rumpel, C., Balesdent, J., Grootes, P., Weber, E., and Kögel-Knabner, I.: Quantification of lignite- and vegetation-derived soil carbon using ${ }^{14} \mathrm{C}$ activity measurements in a forested chronosequence, Geoderma, 112, 155-166, 2003.

Schaaf, W., Bens, B., Fischer, A., Gerke, H. H., Gerwin, W., Grünewald, U., Holländer, H. M., Kögel-Knabner, I., Mutz, M., Schloter, M., Schulin, R., Veste, M., Winter, S., and Hüttl, R. F.: Patterns and processes of initial terrestrial-ecosystem development, J. Plant Nutr. Soil Sc., 174, 229-239, 2011.

20 Schaefer, J. and Stejskal, E. O.: Carbon-13 nuclear magnetic resonance of polymers spinning at magic angle, J. Am. Chem. Soc., 98, 1031-1032, 1976.

Scharpenseel, H. W. and Becker-Heidmann, P.: Twenty-five years of radiocarbon dating soils: paradigm of erring and learning, Radiocarbon, 34, 541-549, 1992.

Scharpenseel, H.-W. and Becker-Heidmann, P.: Shifts in ${ }^{14} \mathrm{C}$ patterns of soil properties due to bomb carbon, including effects of morphogenetic and turbation processes, Radiocarbon, 31, 627-636, 1997.

Schwertmann, U.: Differenzierung der Eisenoxide des Bodens durch Extraktion mit Ammoniumoxalat-Lösung, Z. Pflanzenernähr. Düng. Bodenkd., 105, 194-202, 1964.

Spröte, R., Fischer, T., Veste, M., Raab, T., Wiehe, W., Lange, Ph., Bens, O., and Hüttl, R. F.: Biological topsoil crusts at early successional stages on Quaternary substrates dumped by mining in Brandenburg, NE Germany, Geomorphologie, 4, 359-370, 2010.

Stach, E., Mackowsky, M.-T., Teichmüller, M., Taylor, G. H., Chandra, D., and Teichmüller, R.: Stach's Textbook of Coal Petrology, Gebrüder Borntraeger, Berlin, 1982.

\section{BGD}

$10,851-894,2013$

Biological soil crusts on initial soils

A. Dümig et al.

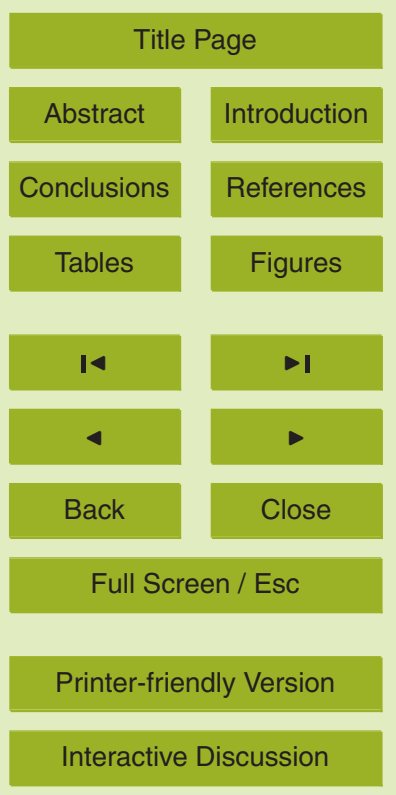


Stuiver, M. and Polach, H. A.: Discussions of reporting ${ }^{14} \mathrm{C}$ data, Radiocarbon, 19, 355-363, 1977.

Terauchi, K. and Kondo, T.: The cyanobacterial Circadian Clock and the KaiC Phosphorylation cycle, in: The Cyanobacteria: Molecular Biology, Genomics and Evolution, edited by: Herrero, A. and Flores, E., Caister Academic Press, Norfolk, 199-215, 2008.

Trumbore, S. E.: Applications of accelerator mass spectrometry to soil science, in: Mass Spectrometry of Soils, edited by: Boutton, T. W. and Yamasaki, S., Marcel Dekker, New York, 311-340, 1996.

Trumbore, S.: Age of soil organic matter and soil respiration: radiocarbon constraints on belowground C dynamics, Ecol. Appl., 10, 399-411, 2000.

Trumbore, S.: Radiocarbon and soil carbon dynamics, Annu. Rev. Earth Planet. Sci., 37, 12.112.20, 2009.

Trumbore, S. E., Vogel, J. S., and Southon, J. R.: AMS ${ }^{14} \mathrm{C}$ measurements of fractionated soil organic matter: an approach to deciphering the soil carbon cycle, Radiocarbon, 31, 644-654,

151989

Trumbore, S. E., Davidson, E. A., de Camargo, P. B., Nepstad, D. C., and Martinelli, L. A.: Belowground cycling of carbon in forests and pastures of eastern Amazonia, Global Biogeochem. Cy., 9, 515-528, 1995.

Veste, M. and Littmann, T.: Dewfall and its geo-ecological implication for biological surface crusts in desert sand dunes (north-western Negev, Israel), J. Arid Land Stud., 16, 139-147, 2006.

Veste, M., Littmann, T., Breckle, S.-W., and Yair, A.: The role of biological soil crusts on desert sand dunes of the north-western Negev (Israel), in: Sustainable Land-Use in Deserts, edited by: Breckle, S.-W., Veste, M., and Wucherer, W., Springer, Heidelberg, New York, Tokyo, 25 357-367, 2001a.

Veste, M., Littmann, T., Friedrich, H., and Breckle, S.-W.: Microclimatic boundary conditions for activity of soil lichen crusts in sand dunes of the north-western Negev desert, Israel, Flora 196, 465-476, 2001b.

Veste, M., Breckle, S.-W., Eggert, K., and Littmann, T.: Vegetation pattern in arid sand dunes controlled by biological soil crusts along a climatic gradient in the Northern Negev desert, Basic Appl. Dryland Res., 5, 1-16, 2011.

BGD

$10,851-894,2013$

Biological soil crusts on initial soils

A. Dümig et al.

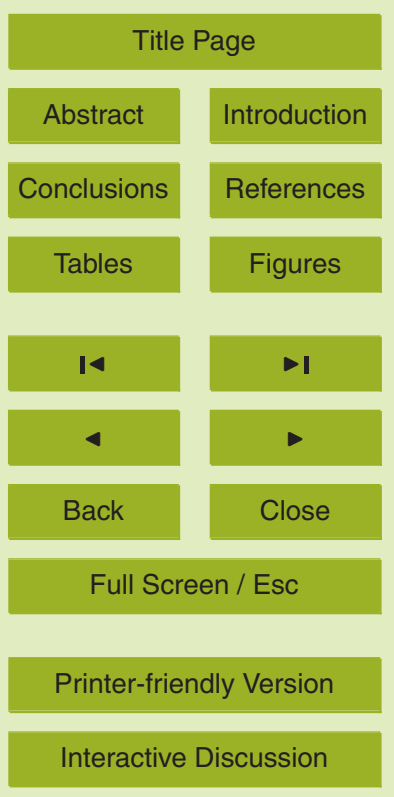


von Lützow, M., Kögel-Knabner, I., Ekschmitt, K., Flessa, H., Guggenberger, G., Matzner, E., and Marschner, B.: SOM fractionation methods: relevance to functional pools and to stabilization mechanisms, Soil Biol. Biochem., 39, 2183-2207, 2007.

Wilske, B., Burgheimer, J., Karnieli, A., Zaady, E., Andreae, M. O., Yakir, D., and Kesselmeier, J.:

BGD

$10,851-894,2013$

Biological soil crusts on initial soils

Wilson, M. A., Pugmire, R. J., and Grant, D. M.: Nuclear magnetic resonance spectroscopy of soils and related materials. Relaxation of ${ }^{13} \mathrm{C}$ nuclei in cross polarization nuclear magnetic resonance experiments, Org. Geochem., 5, 121-129, 1983.

Yair, A., Almog, R., and Veste, M.: Differential hydrological response of biological topsoil crusts along a rainfall gradient in a sandy arid area: Northern Negev desert, Israel, Catena, 87, 326-333, 2011.

Zaady, E., Ben-David, E. A., Sher, Y., Tzirkin, R., and Nejidat, A.: Inferring biological soil crust successional stage using combined PLFA, DGGE, physical and biophysiological analyses, Soil Biol. Biochem., 42, 842-849, 2010.

Zhao, H.-L., Guo, Y.-R., Zhou, R.-L., and Drake, S.: Biological soil crust and surface soil properties in different vegetation types of Horqin Sand Land, China, Catena, 82, 70-76, 2010.

\section{A. Dümig et al.}

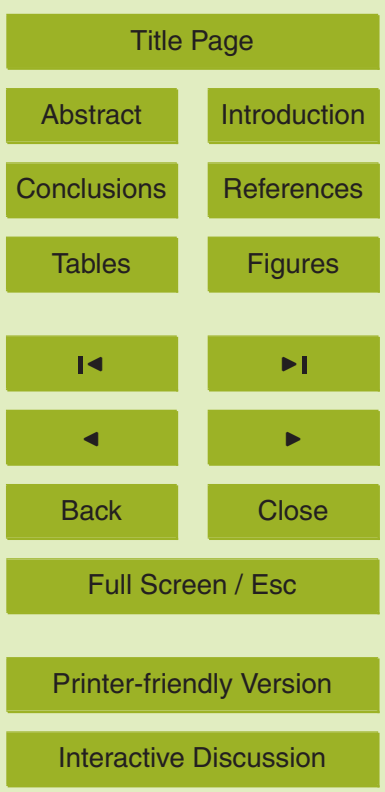


BGD

$10,851-894,2013$

Biological soil crusts on initial soils

Table 1. Characteristics of biological soil crusts (BSCs) and corresponding substrates from both sand dunes (mean values).

\begin{tabular}{|c|c|c|c|c|c|c|c|c|c|c|c|c|c|c|c|c|c|c|c|c|c|}
\hline \multirow[t]{3}{*}{ Site } & \multirow[t]{3}{*}{ Samples $^{a}$} & \multicolumn{13}{|c|}{ Bulk material } & \multicolumn{7}{|c|}{ Fraction $<63 \mu \mathrm{m}$} \\
\hline & & \multirow{2}{*}{$\begin{array}{l}\mathrm{OG}_{\mathrm{tot}} \\
\mathrm{mgg}^{-1}\end{array}$} & \multirow{2}{*}{$\begin{array}{l}\text { Lignite-C } \\
\% \text { of } \mathrm{OC}_{\text {tot }}\end{array}$} & \multirow{2}{*}{$\begin{array}{c}\text { Recent OC } \\
\mathrm{mg} \mathrm{g}^{-1}\end{array}$} & \multirow{2}{*}{$\stackrel{\mathrm{N}}{\mathrm{mg} \mathrm{g}^{-1}}$} & \multirow{2}{*}{$\begin{array}{l}\mathrm{C} / \mathrm{N} \\
\text { ratio }\end{array}$} & \multirow{2}{*}{$\frac{\mathrm{Al}_{\mathrm{d}}{ }^{\mathrm{b}}}{\mathrm{mg} \mathrm{g}^{-1}}$} & \multirow[t]{2}{*}{$\mathrm{Fe}_{\mathrm{d}}$} & \multirow[t]{2}{*}{$\mathrm{Si}_{d}$} & \multirow[t]{2}{*}{$\mathrm{Al}_{\mathrm{o}}$} & \multirow[t]{2}{*}{$\mathrm{Fe}_{0}$} & \multirow[t]{2}{*}{$\mathrm{Si}_{\mathrm{o}}$} & \multirow{2}{*}{$\begin{array}{l}\mathrm{Fe}_{0} / \\
\mathrm{Fe}_{\mathrm{d}}\end{array}$} & \multirow{2}{*}{$\begin{array}{c}\mathrm{BD} \\
\mathrm{gcm}^{-3}\end{array}$} & \multicolumn{3}{|c|}{ Texture $^{\mathrm{C}}$} & \multirow{2}{*}{$\begin{array}{l}\text { Portion in } \\
\text { mass-\% }\end{array}$} & \multirow{2}{*}{$\begin{array}{c}\mathrm{OC} \\
\mathrm{mg} \mathrm{g}^{-1}\end{array}$} & \multirow{2}{*}{$\begin{array}{c}N_{\mathrm{t}} \\
\mathrm{mgg}^{-1}\end{array}$} & \multirow{2}{*}{$\begin{array}{l}\mathrm{C} / \mathrm{N} \\
\text { ratio }\end{array}$} \\
\hline & & & & & & & & & & & & & & & Sand & Silt & Clay & & & & \\
\hline \multirow{10}{*}{ 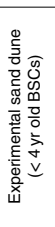 } & BSC-ED1 a & 3.0 & 26 & 2.2 & 0.3 & 10 & 0.6 & 1.1 & 0.3 & 0.5 & 0.4 & 0.1 & 0.4 & & 97 & 1 & 2 & 1.4 & 66.1 & 4.7 & 14 \\
\hline & BSC-ED2 a & 4.5 & 29 & 3.2 & 0.4 & 11 & 0.6 & 1.0 & 0.3 & 0.5 & 0.4 & 0.0 & 0.4 & & 97 & 1 & 2 & 1.3 & 92.8 & 7.5 & 14 \\
\hline & BSC-ED3 m & 8.5 & 39 & 5.2 & 0.7 & 13 & 0.5 & 0.9 & 0.3 & 0.4 & 0.4 & 0.0 & 0.4 & & 96 & 1 & 2 & & & 4.9 & 15 \\
\hline & BSC-ED4 m & 5.1 & 30 & 3.6 & 0.5 & 11 & 0.6 & 0.9 & 0.3 & 0.4 & 0.4 & 0.0 & 0.4 & & 97 & 1 & 2 & 1.6 & 67.7 & 4.8 & 14 \\
\hline & BSC-ED5 m & 5.4 & 21 & 4.3 & 0.4 & 15 & 0.7 & 1.1 & 0.4 & 0.5 & 0.4 & 0.0 & 0.4 & & 96 & 1 & 3 & 1.9 & 61.7 & 3.5 & 18 \\
\hline & Substrate-ED1 & 0.9 & 42 & 0.5 & 0.1 & 9 & 0.5 & 0.9 & 0.3 & 0.5 & 0.3 & 0.1 & 0.4 & 1.6 & 98 & 0 & 2 & 0.7 & 45.7 & 2.2 & 21 \\
\hline & Substrate-ED2 & 1.2 & 52 & 0.6 & 0.1 & 12 & 0.5 & 0.9 & 0.3 & 0.5 & 0.4 & 0.1 & 0.4 & & 99 & & 1 & $\begin{array}{l}1.2 \\
1.2\end{array}$ & & 2.7 & 16 \\
\hline & Substrate-ED3 & 1.2 & 43 & 0.7 & 0.1 & 12 & 0.5 & 0.9 & 0.3 & 0.5 & 0.3 & 0.1 & 0.4 & 1.6 & 98 & 1 & 2 & 1.3 & 38.1 & 2.4 & 16 \\
\hline & Substrate-ED4 & 1.1 & 52 & 0.5 & 0.1 & 11 & 0.6 & 0.9 & 0.3 & 0.4 & 0.3 & 0.1 & 0.3 & 1.6 & 98 & & 2 & 0.8 & 40.6 & 2.2 & 19 \\
\hline & Substrate-ED5 & 1.2 & 50 & 0.6 & 0.1 & 12 & 0.5 & 0.9 & 0.3 & 0.5 & 0.3 & 0.1 & 0.4 & 1.6 & 98 & 1 & 1 & 1.3 & 34.4 & 2.0 & 19 \\
\hline \multirow{10}{*}{ 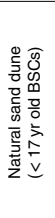 } & BSC-ND1 mobile & 0.7 & 15 & 0.6 & 0.0 & nd & 0.6 & 0.7 & 0.4 & 0.5 & 0.3 & 0.1 & 0.4 & & nd & nd & nd & 0.3 & 69.1 & 6.3 & 11 \\
\hline & BSC-ND2 a & 1.6 & 10 & 1.4 & 0.1 & 12 & 0.5 & 0.8 & 0.4 & 0.6 & 0.3 & 0.1 & 0.3 & & nd & nd & nd & 0.8 & 100.2 & 10.7 & 9 \\
\hline & BSC-ND3 a & 2.9 & 9 & 2.7 & 0.2 & 14 & 0.5 & 0.7 & 0.3 & 0.5 & 0.3 & 0.1 & 0.4 & & nd & nd & nd & 0.8 & 147.2 & 14.1 & 10 \\
\hline & BSC-ND4 m & $\begin{array}{l}.9 \\
8.7\end{array}$ & 8 & 8.0 & 0.4 & 23 & 0.5 & 0.7 & 0.3 & $\begin{array}{l}0.5 \\
0.5\end{array}$ & 0.2 & 0.1 & $\begin{array}{l}0.4 \\
0.4\end{array}$ & & nd & nd & nd & $\begin{array}{l}0.0 \\
0.9\end{array}$ & 111.5 & 9.2 & 12 \\
\hline & BSC-ND5 m & 9.6 & 8 & 8.9 & 0.4 & 26 & 0.5 & 0.9 & 0.4 & 0.4 & 0.2 & 0.1 & 0.3 & & nd & nd & nd & 1.0 & 134.9 & 10.0 & 14 \\
\hline & Substrate-ND1 & 0.9 & 14 & 0.7 & 0.0 & nd & 0.6 & 0.9 & 0.5 & 0.6 & 0.3 & 0.1 & 0.3 & 1.6 & nd & nd & nd & 0.7 & 66.3 & 5.4 & 12 \\
\hline & Substrate-ND2 & 0.7 & 15 & 0.6 & 0.0 & nd & 0.5 & 0.6 & 0.4 & 0.5 & 0.2 & 0.1 & 0.3 & 1.5 & nd & nd & nd & 0.6 & 43.0 & 3.1 & 14 \\
\hline & Substrate-ND3 & 0.7 & 14 & 0.6 & 0.0 & nd & 0.5 & 0.6 & 0.4 & 0.4 & 0.2 & 0.1 & 0.3 & 1.5 & nd & nd & nd & 0.5 & 73.1 & 5.6 & 13 \\
\hline & & 2.0 & 9 & 1.9 & 0.1 & 17 & 0.6 & 0.7 & 0.4 & 0.5 & 0.2 & 0.1 & 0.3 & 1.5 & nd & nd & nd & & 119.6 & 9.7 & 12 \\
\hline & Substrate-ND5 & 1.9 & 11 & 1.7 & 0.1 & 21 & 0.7 & 0.8 & 0.5 & 0.5 & 0.3 & 0.1 & 0.3 & 1.4 & nd & nd & nd & 1.0 & 98.5 & 6.8 & 14 \\
\hline
\end{tabular}

${ }^{\mathrm{a}}$ mobile $=$ mobile sand, $\mathrm{a}=$ algae-dominated BSC, $\mathrm{m}=$ moss-dominated BSC

${ }^{\mathrm{b}}$ ditihionite-citrate-bicarbonate and oxalate extraction

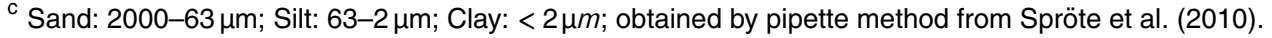

\section{A. Dümig et al.}

Title Page

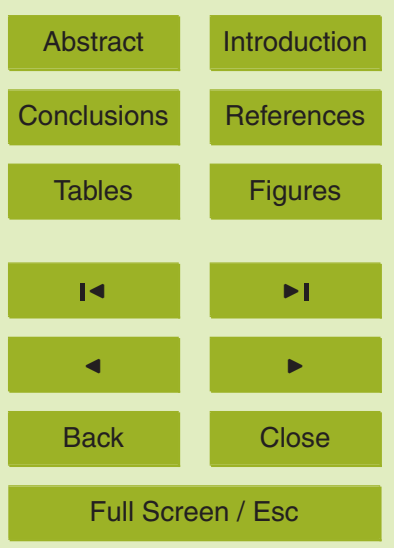

Printer-friendly Version

Interactive Discussion 
BGD

$10,851-894,2013$

Biological soil crusts on initial soils

Table 2. ${ }^{14} \mathrm{C}$ contents and functional groups according to solid-state ${ }^{13} \mathrm{C}$ NMR spectroscopy for fractions $<63 \mu \mathrm{m}$.

\begin{tabular}{|c|c|c|c|c|c|c|c|c|c|c|c|c|c|}
\hline \multirow{3}{*}{ Site } & \multirow{3}{*}{$\begin{array}{l}\text { Fraction }^{\mathrm{a}} \\
<63 \mu \mathrm{m}\end{array}$} & \multirow{3}{*}{$\begin{array}{l}\mathrm{OC}_{\text {tot }} \\
\mathrm{mg} \mathrm{g}^{-1}\end{array}$} & \multirow{3}{*}{$\begin{array}{l}\mathrm{C} / \mathrm{N} \\
\text { ratio }\end{array}$} & \multirow{3}{*}{$\begin{array}{l}\text { Lignite-C in } \\
\% \text { of } \mathrm{OC}_{\text {tot }}\end{array}$} & \multirow{3}{*}{$\begin{array}{c}\text { Recent OC } \\
\mathrm{mgg}^{-1}\end{array}$} & \multirow{3}{*}{$\begin{array}{c}{ }^{14} \mathrm{C} \text { content } \\
(\mathrm{pMC})^{\mathrm{b}}\end{array}$} & \multirow{3}{*}{$\begin{array}{c}{ }^{14} \mathrm{C} \text { age } \\
\text { yr BP }\end{array}$} & \multicolumn{6}{|c|}{ Functional group (ppm) according to solid-state ${ }^{13} \mathrm{C}$ NMR spectroscopy } \\
\hline & & & & & & & & Carboxyl C & Aromatic C & O-alkyl C & $\mathrm{N}$-alkyl C & Alkyl C & Alkyl C/ \\
\hline & & & & & & & & $245-160$ & $160-110$ & $110-60$ & $60-45$ & $45-0$ & O-alkyl C \\
\hline \multirow{10}{*}{ 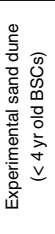 } & BSC-ED1 a & 52.7 & 16 & 26 & 38.8 & 77.2 & 2025 & 15 & 22 & 25 & 7 & 32 & 1.3 \\
\hline & BSC-ED2 a & 71.7 & 15 & 29 & 51.1 & 74.7 & 2280 & 15 & 19 & 26 & 8 & 32 & 1.2 \\
\hline & BSC-ED3 m & 72.9 & 14 & 39 & 44.8 & 64.4 & 3475 & 19 & 19 & 24 & 6 & 32 & 1.3 \\
\hline & BSC-ED4 m & 73.4 & 13 & 30 & 51.6 & 73.6 & 2400 & 12 & 18 & 28 & 8 & 34 & 1.2 \\
\hline & BSC-ED5 m & 73.8 & 17 & 21 & 58.0 & 82.3 & 1505 & 16 & 18 & 29 & 7 & 30 & 1.0 \\
\hline & Substrate-ED1 & 45.4 & 17 & 42 & 26.2 & 60.4 & 3990 & 20 & 24 & 17 & 6 & 32 & 1.9 \\
\hline & Substrate-ED2 & 46.9 & 15 & 52 & 22.3 & 49.9 & 5525 & 19 & 21 & 24 & 7 & 30 & 1.3 \\
\hline & Substrate-ED3 & 40.0 & 19 & 43 & 22.9 & 59.9 & 4055 & 20 & 25 & 22 & 6 & 27 & 1.2 \\
\hline & Substrate-ED4 & 42.8 & 18 & 52 & 20.6 & 50.3 & 5455 & 17 & 20 & 25 & 6 & 32 & 1.3 \\
\hline & Substrate-EDS & 43.7 & 15 & 50 & 21.7 & 52.2 & 5170 & 21 & 18 & 28 & 6 & 27 & 1.0 \\
\hline \multirow{10}{*}{ 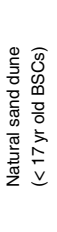 } & BSC-ND1 mobile & 53.4 & 11 & 15 & 45.6 & 92.5 & 570 & 14 & 16 & 32 & 9 & 29 & 0.9 \\
\hline & BSC-ND2 a & 89.8 & 10 & 10 & 80.7 & 97.3 & 165 & 15 & 10 & 38 & 9 & 29 & 0.8 \\
\hline & BSC-ND3 a & 131.9 & 11 & 9 & 119.8 & 98.3 & 80 & 15 & 10 & 38 & 8 & 28 & 0.7 \\
\hline & BSC-ND4 m & 144.7 & 12 & 8 & 132.8 & 99.3 & -5 & 16 & 9 & 44 & 7 & 24 & 0.5 \\
\hline & BSC-ND5 m & 146.1 & 13 & 8 & 1347 & 99.8 & -40 & 15 & 11 & 47 & 7 & 21 & 0.5 \\
\hline & Substrate-ND1 & 66.3 & 12 & 14 & 57.0 & 93.0 & 525 & 23 & 16 & 25 & 7 & 30 & 1.2 \\
\hline & Substrate-ND2 & 43.0 & 14 & 15 & 36.6 & 92.3 & 585 & 18 & 17 & 29 & 7 & 29 & 1.0 \\
\hline & Substrate-ND3 & 73.1 & 13 & 14 & 62.7 & 92.9 & 535 & 22 & 15 & 26 & 7 & 31 & 1.2 \\
\hline & Substrate-ND4 & 119.6 & 12 & 9 & 109.0 & 98.6 & 55 & 13 & 11 & 35 & 9 & 32 & 0.9 \\
\hline & Substrate-ND5 & 98.5 & 14 & 11 & 88.1 & 96.8 & 205 & 15 & 11 & 39 & 8 & 27 & 0.7 \\
\hline
\end{tabular}

${ }^{a}$ mobile $=$ mobile sand, $a$ = algae-dominated BSC, $\mathrm{m}=$ moss-dominated BSC

${ }^{b}$ percent modern carbon $(100 \mathrm{pMC}=1950 \mathrm{AD})$.

\section{A. Dümig et al.}

Title Page

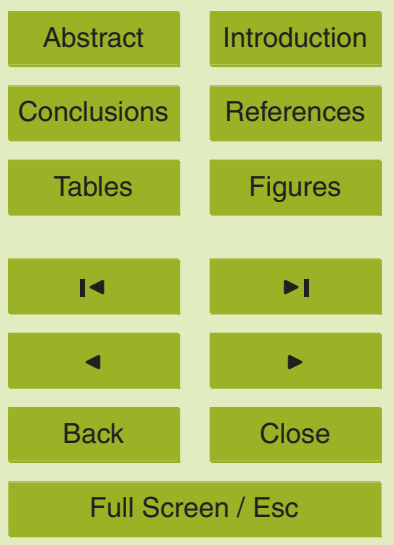

Printer-friendly Version

Interactive Discussion 


\section{BGD}

$10,851-894,2013$

Biological soil crusts on initial soils

Table 3. BSC-derived $\mathrm{OC}$ input $\left(\mathrm{OC}_{\mathrm{BSC}}-\mathrm{OC}_{\text {substrate }}\right)$ for bulk materials and fractions $<63 \mu \mathrm{m}$.

\begin{tabular}{|c|c|c|c|c|c|}
\hline \multirow[b]{3}{*}{ Samples ${ }^{a}$} & \multicolumn{4}{|c|}{ BSC-derived $\mathrm{OC}$ input $\left(\mathrm{OC}_{\mathrm{BSC}}-\mathrm{OC}_{\text {substrate }}\right)$ in $\mathrm{mg} \mathrm{g}^{-1}$} & \multirow{3}{*}{$\begin{array}{c}\text { recent } \\
\text { OC input } \\
\text { in } \mathrm{g} \mathrm{m}^{-2} \mathrm{a}^{-1}\end{array}$} \\
\hline & \multicolumn{2}{|c|}{ Fraction $<63 \mu \mathrm{m}$} & \multicolumn{2}{|c|}{ Bulk material } & \\
\hline & with lignite & without lignite & with lignite & without lignite & \\
\hline \multicolumn{6}{|c|}{ Experimental sand dune (< 4 yr old BSCs) } \\
\hline ED1 a & 7.3 & 12.6 & 21 & 1.7 & 2.0 \\
\hline ED2 a & 24.9 & 28.8 & 3.4 & 2.7 & 2.2 \\
\hline ED3 m & 32.9 & 21.9 & 7.3 & 4.6 & 7.2 \\
\hline ED4 m & 30.6 & 31.0 & 4.0 & 3.1 & 12.3 \\
\hline ED5 m & 30.1 & 36.2 & 4.2 & 3.6 & 21.9 \\
\hline \multicolumn{6}{|c|}{ Natural sand dune (<17yr old BSCs) } \\
\hline ND1 mobile & -13.0 & 0.0 & 0.0 & 0.0 & 0.0 \\
\hline ND2 a & 46.8 & 44.0 & 0.9 & 0.8 & 0.2 \\
\hline ND3 a & 58.8 & 57.1 & 2.2 & 2.0 & 0.5 \\
\hline ND4 m & 25.0 & 23.8 & 6.7 & 6.2 & 2.7 \\
\hline ND5 m & 47.6 & 46.6 & 7.7 & 7.2 & 3.0 \\
\hline
\end{tabular}
A. Dümig et al.

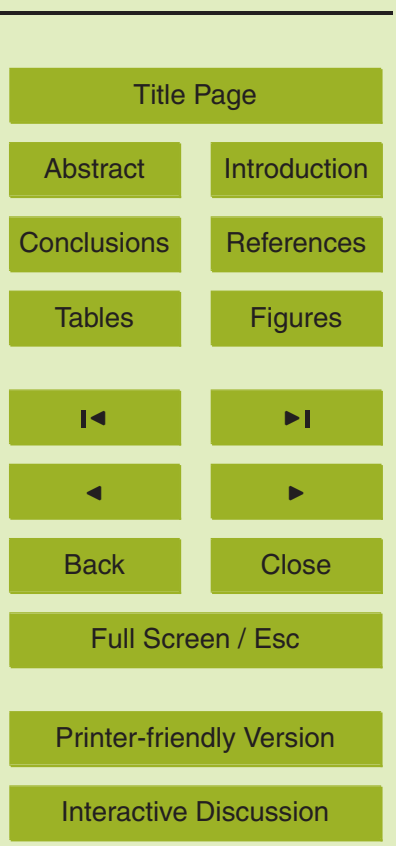

${ }^{\mathrm{a}}$ mobile $=$ mobile sand, $\mathrm{a}=$ algae-dominated $\mathrm{BSC}, \mathrm{m}=$ moss-dominated $\mathrm{BSC}$ 
BGD

$10,851-894,2013$

Biological soil crusts on initial soils corresponding substrates (mean values, standard deviation in brackets).

\begin{tabular}{|c|c|c|c|c|c|c|c|c|c|c|c|}
\hline \multirow[t]{2}{*}{ Site } & \multirow[t]{2}{*}{ Samples $^{a}$} & \multirow{2}{*}{$\begin{array}{c}\text { Carbohydrate-C } \\
\mathrm{mg} \mathrm{g}^{-1} \mathrm{OC}\end{array}$} & \multicolumn{8}{|c|}{ Relative proportions of monosaccharide-C (\%) } & \multirow[b]{2}{*}{$G M / A X^{b}$} \\
\hline & & & Rhamnose & Fucose & Ribose & Arabinose & Xylose & Mannose & Galactose & Glucose & \\
\hline \multirow{12}{*}{ 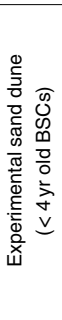 } & BSC - bulk material & & & & & & & & & & \\
\hline & BSC-ED1 a & $342.4(17.4)$ & $2.1(0.3)$ & $0.4(0.6)$ & $0.0(0.0)$ & $5.7(0.6)$ & $2.5(1.1)$ & $29.5(0.3)$ & $32.0(1.4)$ & $27.9(0.9)$ & $7.8(17)$ \\
\hline & BSC-ED2 a & $430.2(38.9)$ & $6.7(1.3)$ & $3.2(0.7)$ & $0.0(0.0)$ & $7.3(0.5)$ & $6.1(0.9)$ & $26.3(0.3)$ & $26.5(0.2)$ & $23.9(0.9)$ & $4.0(0.4)$ \\
\hline & BSC-ED3 m & $542.5(28.4)$ & $6.7(0.4)$ & $3.8(0.8)$ & $0.0(0.0)$ & $8.5(0.5)$ & $7.8(1.6)$ & $21.1(0.6)$ & $25.8(1.3)$ & $26.3(1.4)$ & $2.9(0.5)$ \\
\hline & BSC-ED4 m & $502.2(20.2)$ & $7.4(0.2)$ & $3.0(0.0)$ & $0.0(0.0)$ & $6.8(0.5)$ & $5.2(0.7)$ & $26.5(0.6)$ & $27.7(0.7)$ & $23.4(0.3)$ & $4.6(0.6)$ \\
\hline & BSC-ED5 m & $557.2(39.0)$ & $6.2(0.8)$ & $1.5(0.4)$ & $0.0(0.0)$ & $6.1(0.4)$ & $6.3(0.8)$ & $24.2(1.1)$ & $30.1(2.5)$ & $25.5(0.3)$ & $4.4(0.3)$ \\
\hline & Substrate - fraction & $<63 \mu \mathrm{m}$ & & & & & & & & & \\
\hline & Substrate-ED1 & $100.4(13.0)$ & $6.2(2.2)$ & $3.8(1.4)$ & $0.1(0.1)$ & $10.0(1.9)$ & $8.9(2.0)$ & $17.8(2.9)$ & $18.5(1.8)$ & $34.6(3.0)$ & $2.0(0.6)$ \\
\hline & Substrate-ED2 & $184.8(29.6)$ & $10.4(1.3)$ & $4.5(1.1)$ & $1.1(1.0)$ & $10.1(1.8)$ & $10.2(2.6)$ & $18.8(3.2)$ & $19.7(0.6)$ & $25.3(4.3)$ & $2.0(0.6)$ \\
\hline & Substrate-ED3 & 204.1 (37.6) & $9.5(0.3)$ & $3.7(0.4)$ & $0.7(0.8)$ & $11.1(0.3)$ & $12.1(1.2)$ & $15.9(0.9)$ & $21.3(1.5)$ & $25.6(2.3)$ & $1.6(0.0)$ \\
\hline & Substrate-ED4 & $168.1(27.1)$ & $9.3(1.0)$ & $3.4(0.7)$ & $0.0(0.0)$ & $8.7(0.8)$ & $7.8(0.9)$ & $21.5(1.4)$ & $21.0(1.0)$ & $28.2(3.0)$ & $2.6(0.3)$ \\
\hline & Substrate-ED5 & $185.4(44.8)$ & $8.8(1.2)$ & $2.8(1.0)$ & $1.0(1.0)$ & $8.3(2.7)$ & $9.2(3.5)$ & $19.0(4.0)$ & $21.8(1.7)$ & $29.1(6.9)$ & $2.6(1.3)$ \\
\hline \multirow{11}{*}{ 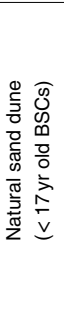 } & BSC - bulk material & & & & & & & & & & \\
\hline & $\begin{array}{l}\text { BSC-ND1 mobile } \\
\text { BSC-ND2 a }\end{array}$ & $\begin{array}{c}91.0(71.1) \\
364.4(24.1)\end{array}$ & $\begin{array}{c}0 .(0.0) \\
2.0(3.2)\end{array}$ & $\begin{array}{l}0.0(0.0) \\
0.0(0.0)\end{array}$ & $\begin{array}{l}0.0(0.0) \\
0.0(0.0)\end{array}$ & $\begin{array}{l}0.0(0.0) \\
1.6(1.4)\end{array}$ & $\begin{array}{l}0.0(0.0) \\
3.1(0.8)\end{array}$ & $\begin{array}{c}8.8(4.6) \\
19.9(1.4)\end{array}$ & $\begin{array}{l}24.6(12.8) \\
24.5(1.7)\end{array}$ & $\begin{array}{c}66.6(17.5) \\
48.9(2.0)\end{array}$ & $\begin{array}{c}\text { nd } \\
6.5(1.8)\end{array}$ \\
\hline & BSC-ND3 a & $517.9(4.5)$ & $8.3(0.4)$ & $7.8(0.4)$ & $0.0(0.0)$ & $10.3(0.3)$ & $11.9(0.5)$ & $17.4(0.2)$ & $20.1(0.9)$ & $24.0(0.3)$ & $1.7(0.0)$ \\
\hline & BSC-ND4 m & $697.8(31.1)$ & $6.5(0.3)$ & $1.3(1.1)$ & $0.0(0.0)$ & $11.3(0.7)$ & $9.1(0.4)$ & $19.8(1.1)$ & $28.3(0.6)$ & $24.4(0.6)$ & $2.4(0.2)$ \\
\hline & BSC-ND5 m & $674.3(38.4)$ & $6.6(0.4)$ & $0.3(0.5)$ & $0.0(0.0)$ & $9.7(0.8)$ & $7.9(0.3)$ & $22.8(1.9)$ & $29.0(0.4)$ & $24.3(0.2)$ & $3.0(0.3)$ \\
\hline & Substrate - fraction & $<63 \mu \mathrm{m}$ & & & & & & & & & \\
\hline & Substrate-ND1 & 189.6 & 10.4 & 3.4 & 0.2 & 6.5 & 7.1 & 20.9 & 22.0 & 29.5 & 3.1 \\
\hline & Substrate-ND2 & 212.3 & 8.5 & 1.8 & 0.0 & 6.0 & 7.0 & 22.1 & 21.5 & 33.2 & 3.4 \\
\hline & Substrate-ND3 & 140.1 & 9.8 & 3.1 & 0.0 & 7.1 & 8.2 & 21.2 & 20.6 & 30.0 & 2.7 \\
\hline & Substrate-ND4 & 260.6 & 11.0 & 4.6 & 0.1 & 10.2 & 9.8 & 19.7 & 24.8 & 19.5 & 2.2 \\
\hline & Substrate-ND5 & 292.9 & 12.1 & 2.9 & 0.0 & 11.4 & 9.0 & 17.3 & 29.1 & 18.3 & 2.3 \\
\hline
\end{tabular}

${ }^{a}$ mobile $=$ mobile sand, $\mathrm{a}=$ algae-dominated BSC, $\mathrm{m}=$ moss-dominated BSC

${ }^{b}$ ratio of galactose plus mannose over arabinose plus xylose.

\section{A. Dümig et al.}

Title Page

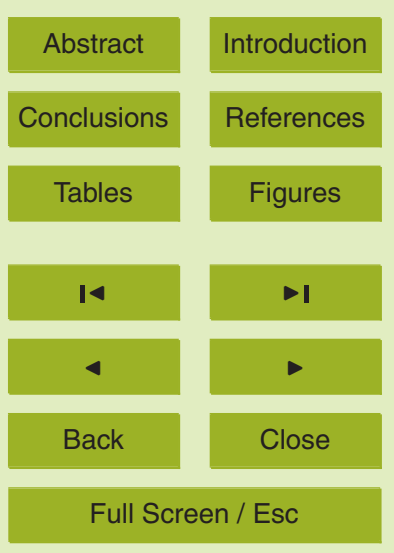

Printer-friendly Version

Interactive Discussion 


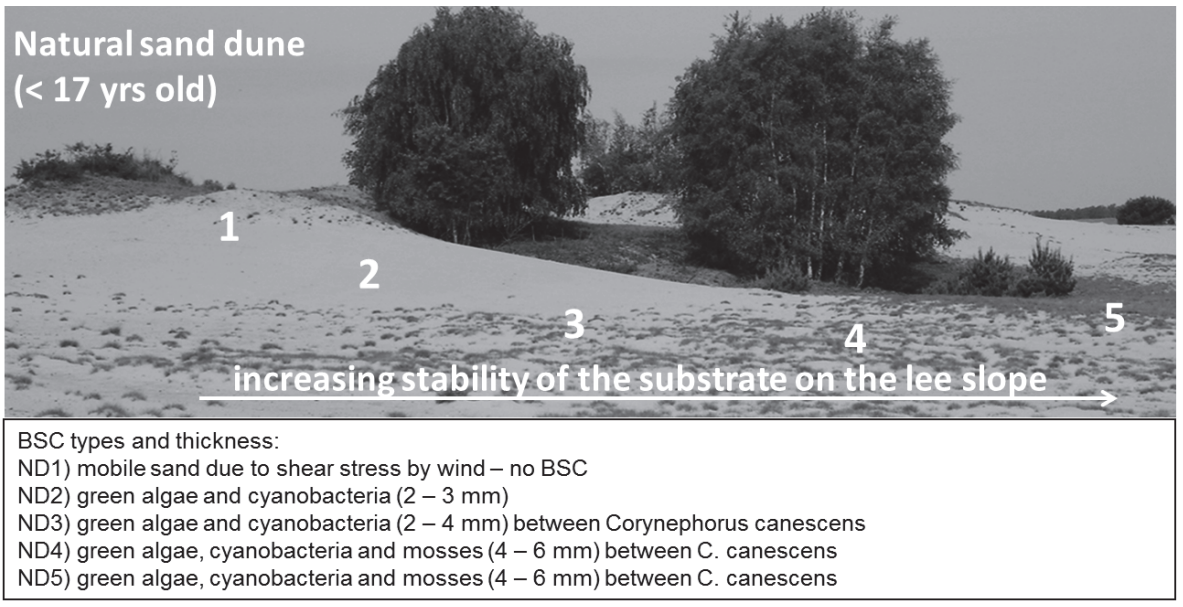

\section{BGD}

10, 851-894, 2013

\section{Biological soil crusts on initial soils}
A. Dümig et al.

\section{Experimental sand dune}

\section{fyearsold}

BSeswere observed-
4 vis before sampling)
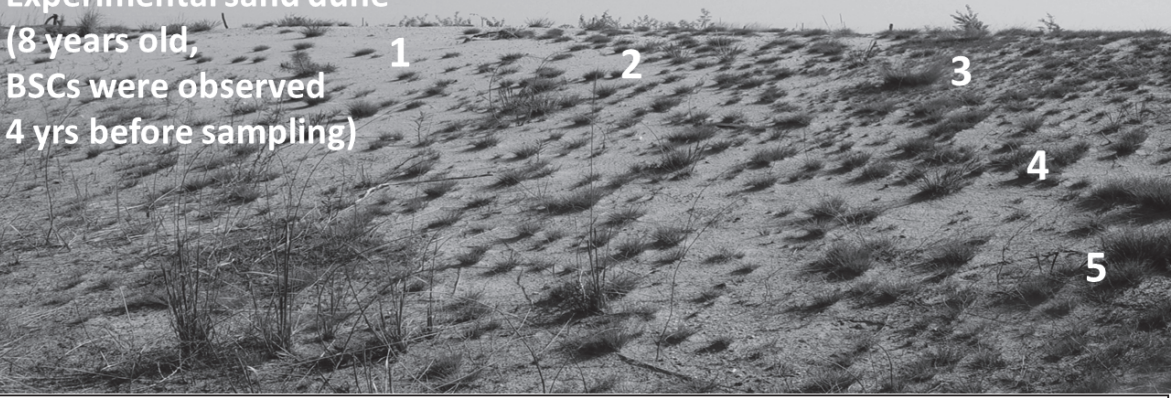

BSC types and thickness:

ED1) green algae and cyanobacteria $(2-3 \mathrm{~mm})$, no vegetation, crest

ED2) green algae and cyanobacteria $(2-3 \mathrm{~mm})$ between sparse cover of Corynephorus canescens, crest

ED3) green algae, cyanobacteria and mosses $(3-4 \mathrm{~mm})$ between dense cover of $C$. canescens, crest

ED4) green algae, cyanobacteria and mosses $(9-10 \mathrm{~mm})$ between dense cover of $C$. canescens, slope

ED5) green algae, cyanobacteria and mosses $(13-15 \mathrm{~mm})$ between dense cover of $C$. canescens, footslope

Fig. 1. The natural (<17yr old BSCs) and experimental sand dune ( $<4 \mathrm{yr}$ old BSCs) with sampling sites and description of BSC types.

\section{Title Page}

\begin{tabular}{|c|c|}
\hline Abstract & Introduction \\
\hline Conclusions & References \\
\hline Tables & Figures \\
\hline I4 \\
\hline 4 \\
\hline Back \\
\hline Full Screen / Esc \\
\hline Printer-friendly Version \\
\hline Interactive Discussion
\end{tabular}

(c) $\underset{\mathrm{Br}}{(1)}$ 


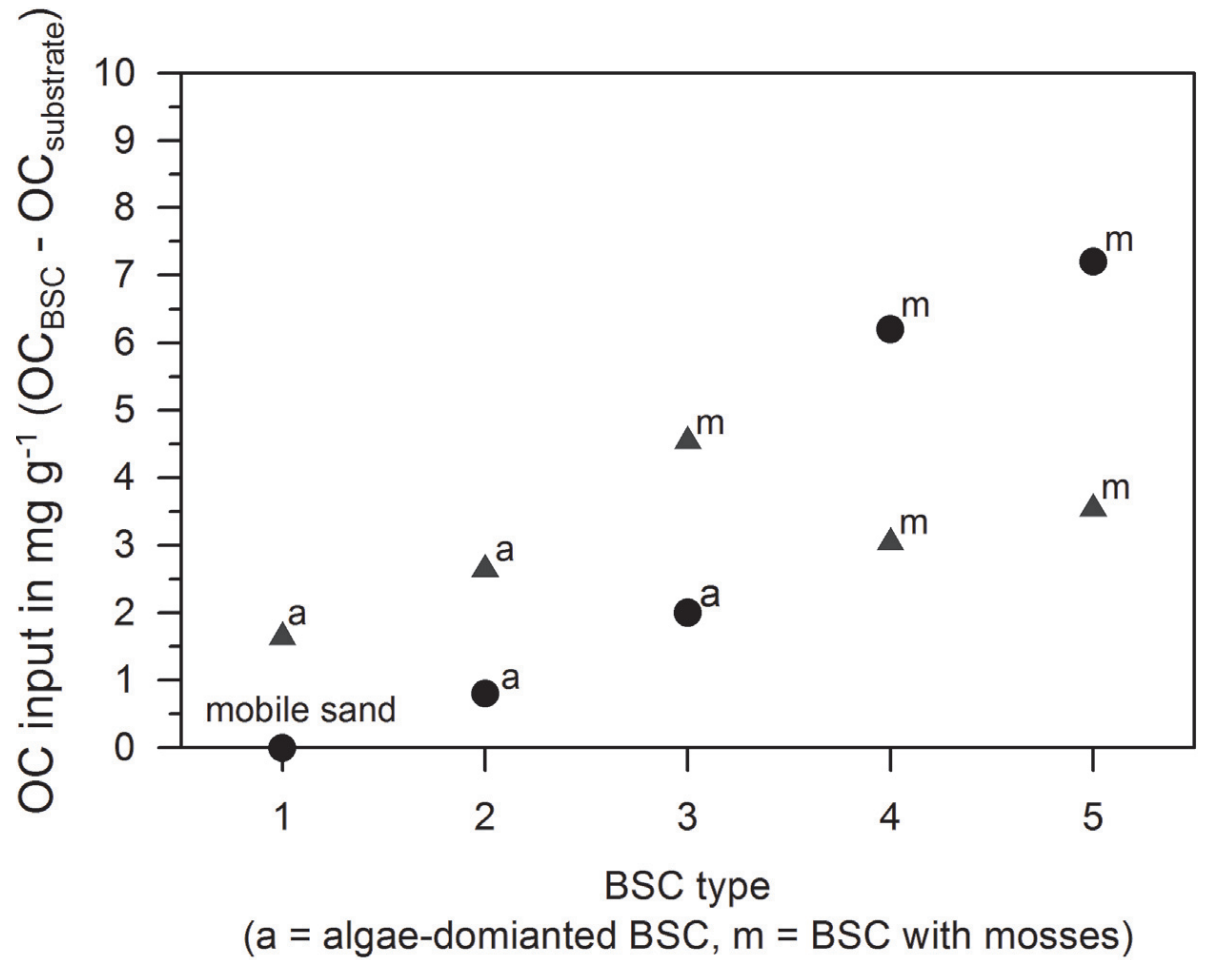

BGD

10, 851-894, 2013

Biological soil crusts on initial soils

A. Dümig et al.

Title Page

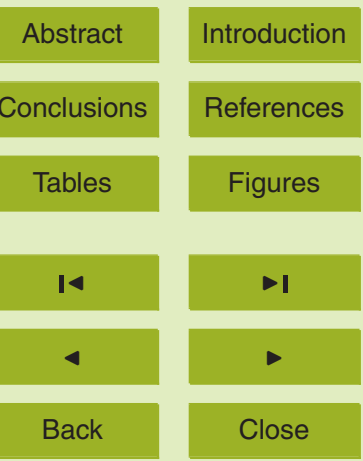

Full Screen / Esc

Fig. 2. BSC-derived input of $\mathrm{OC}\left(\mathrm{OC}_{\mathrm{BSC}}-\mathrm{OC}_{\text {substrate }}\right)$ at the experimental ( $\mathbf{\Delta},<4 \mathrm{yr}$ old $\left.\mathrm{BSCs}\right)$

Printer-friendly Version

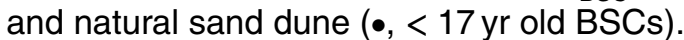

Interactive Discussion 


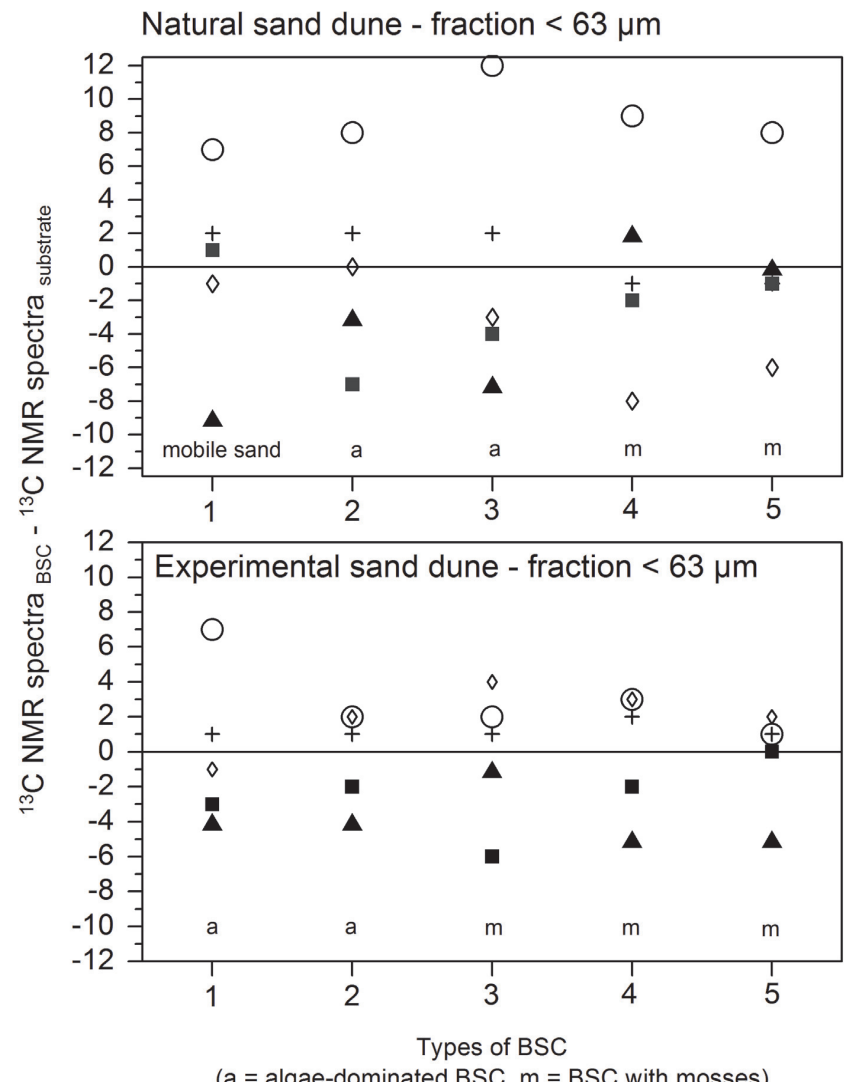

( $\mathrm{a}=$ algae-dominated BSC, $\mathrm{m}=\mathrm{BSC}$ with mosses)
BGD

$10,851-894,2013$

Biological soil crusts on initial soils

A. Dümig et al.

Title Page

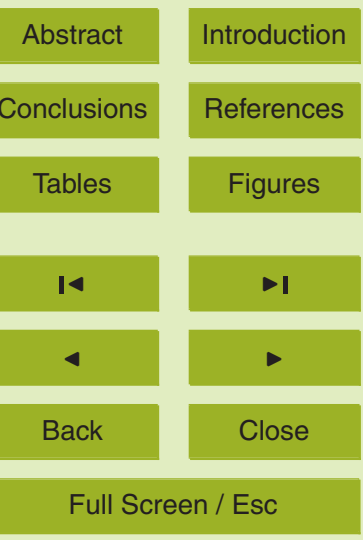

Printer-friendly Version

Interactive Discussion

Fig. 3. Chemical composition of BSC-derived OC as shown from ${ }^{13} \mathrm{C}$ NMR spectra $(0=\mathrm{O}$-alkyl $\mathrm{C},+=\mathrm{N}$-alkyl $\mathrm{C}, \diamond=$ alkyl $\mathrm{C}, \boldsymbol{\square}=$ aromatic $\mathrm{C}, \boldsymbol{\Delta}=$ carboxyl $\mathrm{C}$ ). 

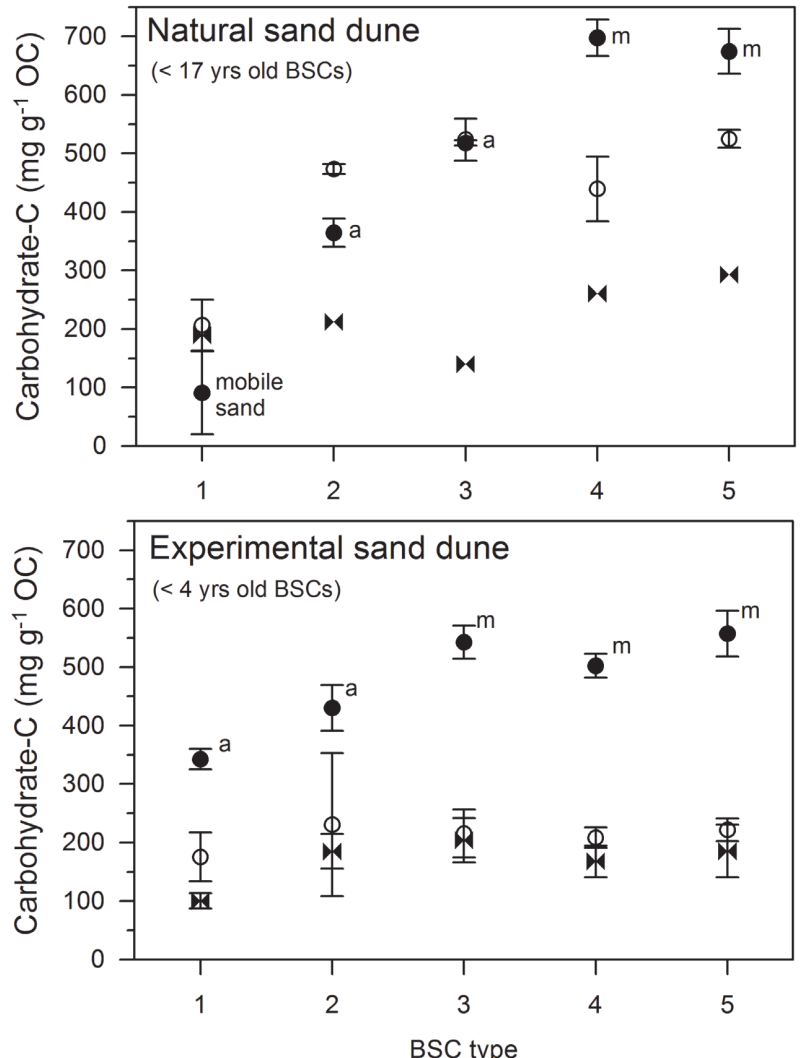

( $\mathrm{a}$ = algae-dominated $\mathrm{BSC}, \mathrm{m}=\mathrm{BSC}$ with mosses $)$

Fig. 4. Carbohydrate-C contents of BSCs (bulk materials and fractions $<63 \mu \mathrm{m}$ ) and substrates (fractions $<63 \mu \mathrm{m}$ ).
I BSC - bulk material $\Phi$ BSC - fraction $<63 \mu \mathrm{m}$

雨 Substrate - fraction $<63 \mu \mathrm{m}$

(error bars represent the standard deviation)

BGD

$10,851-894,2013$

Biological soil crusts on initial soils
A. Dümig et al.

Title Page

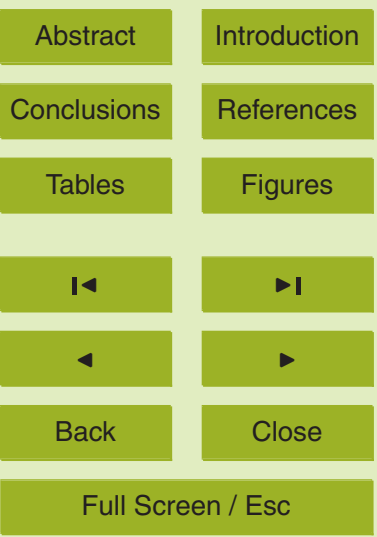

Printer-friendly Version

Interactive Discussion 


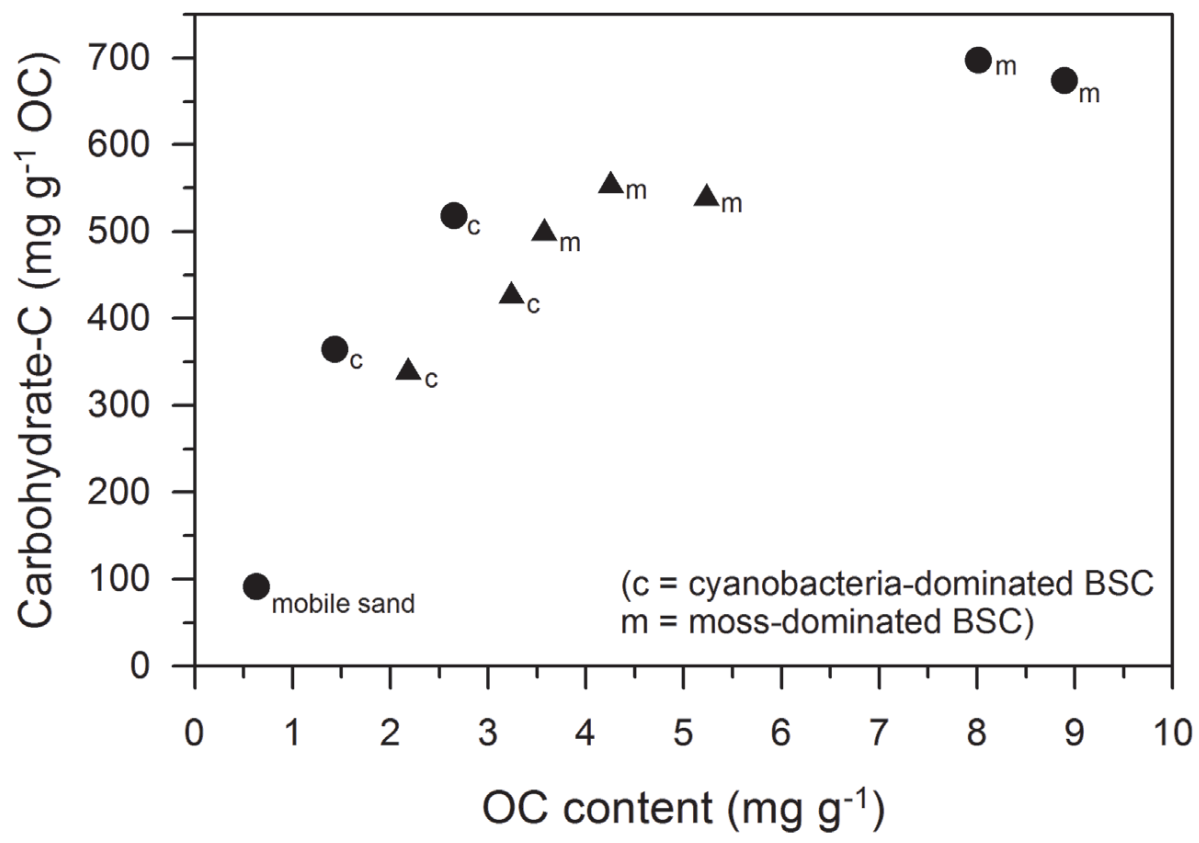

Fig. 5. Relationship between OC content and carbohydrate-C of BSCs (bulk materials) at the experimental $(\boldsymbol{\Delta})$ and natural sand dune $(\bullet)$.
BGD

$10,851-894,2013$

Biological soil crusts on initial soils
A. Dümig et al.

Title Page

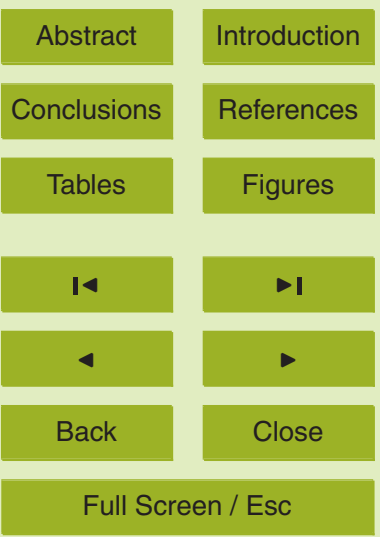

Printer-friendly Version

Interactive Discussion 
BGD

10, 851-894, 2013

\section{Biological soil crusts} on initial soils
A. Dümig et al.

Title Page

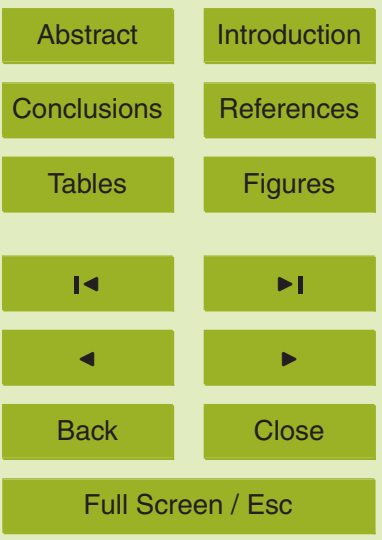

Printer-friendly Version

Interactive Discussion 


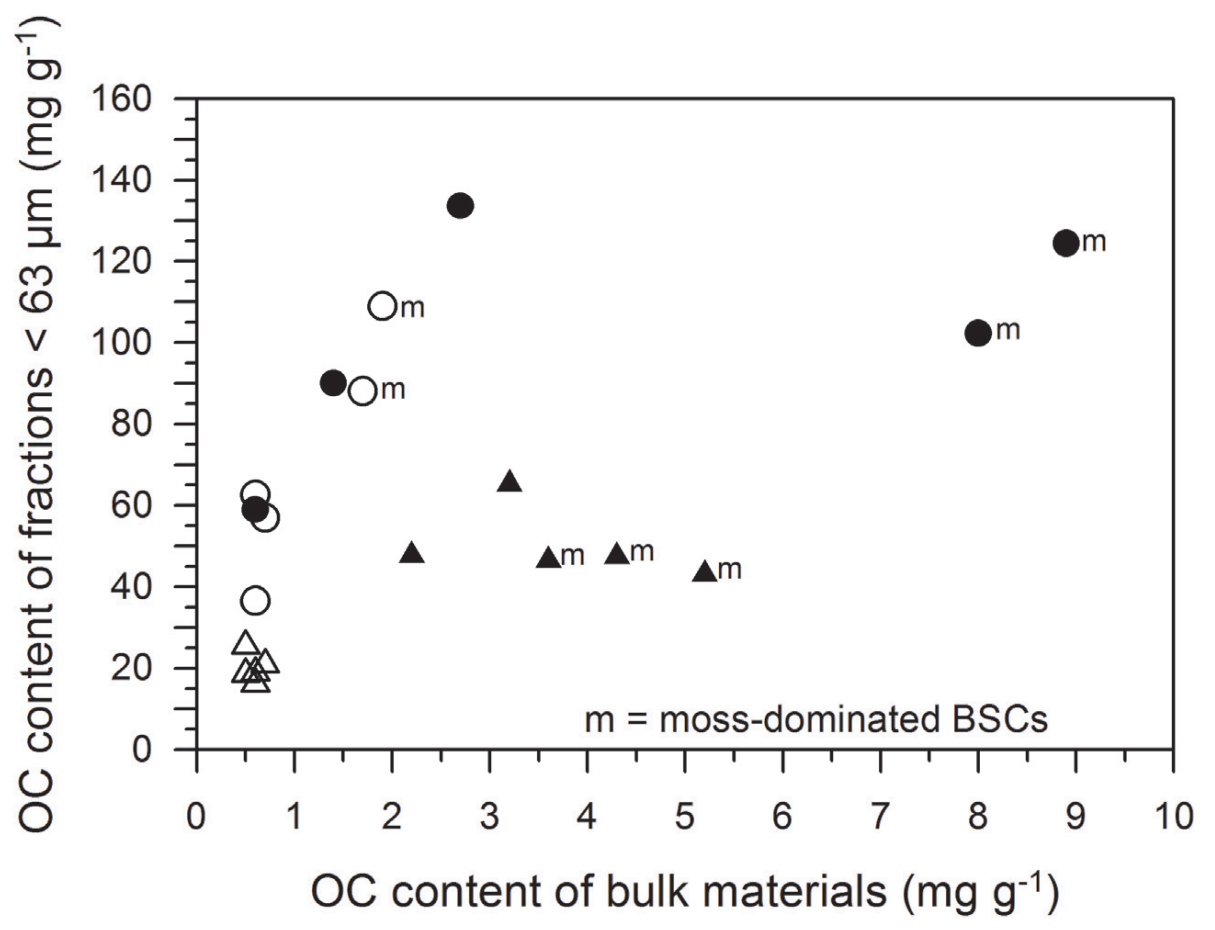

Fig. 7. OC content (without lignite-C) of bulk materials and fractions $<63 \mu \mathrm{m}$ from BSCs (filled symbols) and substrates (not filled symbols) at the experimental $(\Delta / \Delta,<4 \mathrm{yr}$ old BSCs) and natural $(\bullet / \circ,<17 \mathrm{yr}$ old BSCs) sand dunes.

\section{BGD}

$10,851-894,2013$

\section{Biological soil crusts} on initial soils
A. Dümig et al.

Title Page

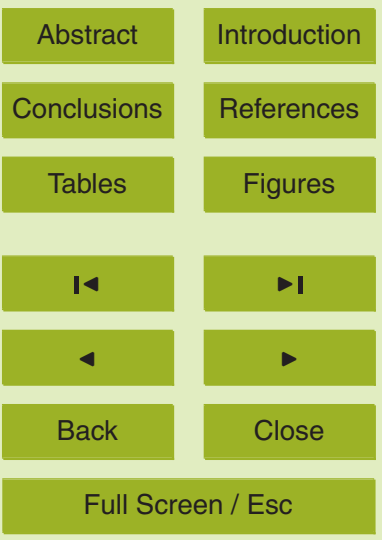

Printer-friendly Version

Interactive Discussion 